

\title{
Systematics and Evolution of Chresta Vell. ex DC. (Vernonieae, Asteraceae)
}

\section{Sistemática e Evolução de Chresta Vell. ex DC. (Vernonieae, Asteraceae)}

Carolina Moriani Siniscalchi

\author{
Tese apresentada ao \\ Instituto de Biociências da \\ Universidade de São Paulo \\ para obtenção do Título de \\ Doutor em Ciências Biológicas \\ na Área de Botânica.
}

\section{Orientador}

José Rubens Pirani (Universidade de São Paulo) Co-orientador

Benoit Loeuille (Universidade Federal de Pernambuco)

São Paulo - 2018 


\begin{tabular}{|} 
Siniscalchi, Carolina Moriani \\
Sistemática e Evolução de Chresta Vell. ex DC. (Vernonieae, \\
Asteraceae) \\
281 páginas \\
Tese (doutorado) - Instituto de Biociências da Univesidade de \\
São Paulo. Departamento de Botânica. \\
1. Filogenômica. 2. Compositae. 3. Taxonomia. 4. Chrestinae. \\
Universidade de São Paulo. Instituto de Biociências. \\
Departamento de Botânica.
\end{tabular}

Comissão Julgadora:

Prof(a). Dr(a).

$$
\text { Prof(a). Dr(a). }
$$

Prof(a). Dr(a).

$$
\text { Prof(a). } \operatorname{Dr}(a) \text {. }
$$


Aos meus pais, Cíntia e Roberto e à minha avó, Judith, meus pilares.
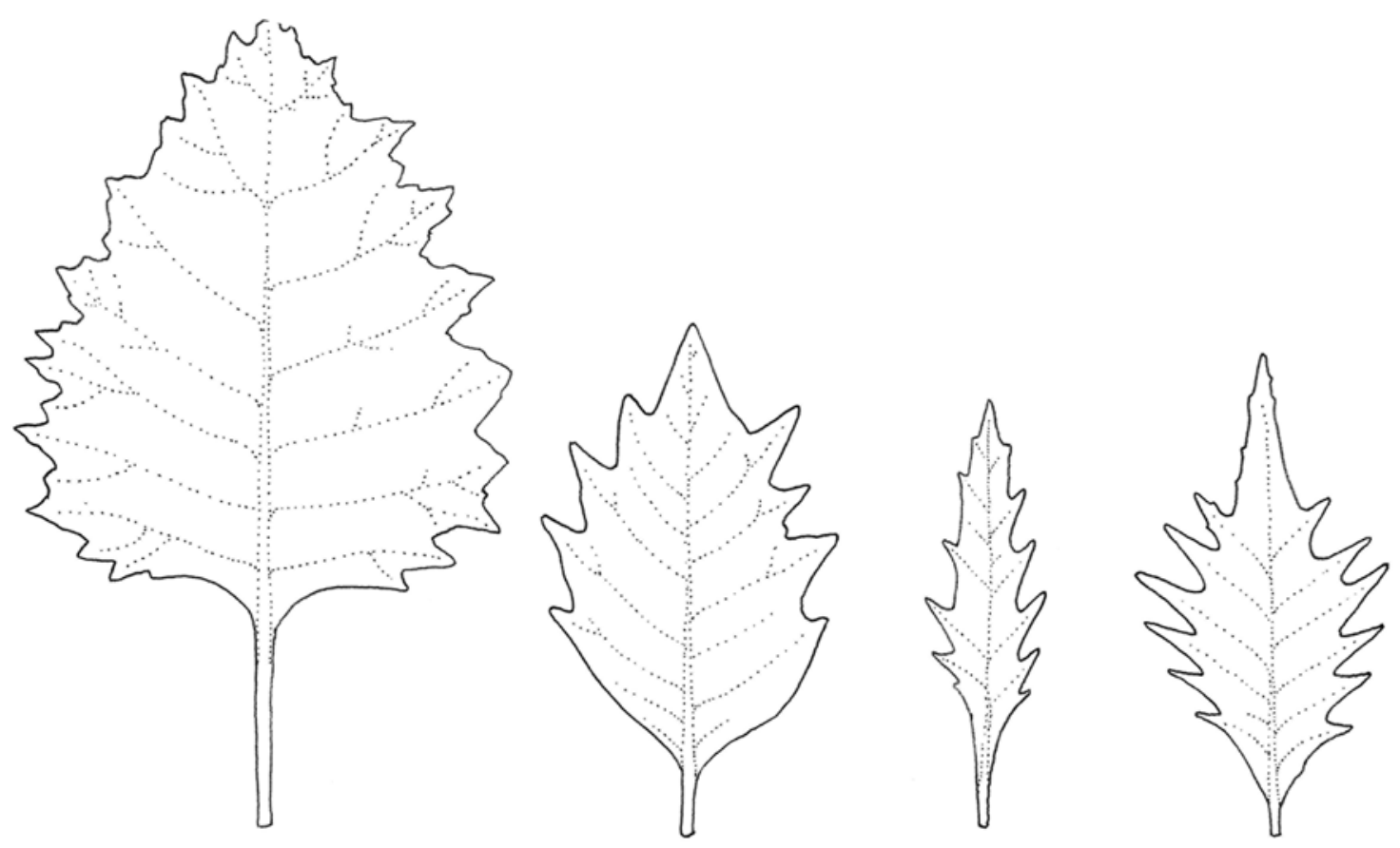
Magno amore in familiam Synantherearum captus...

—Lessing, 1829

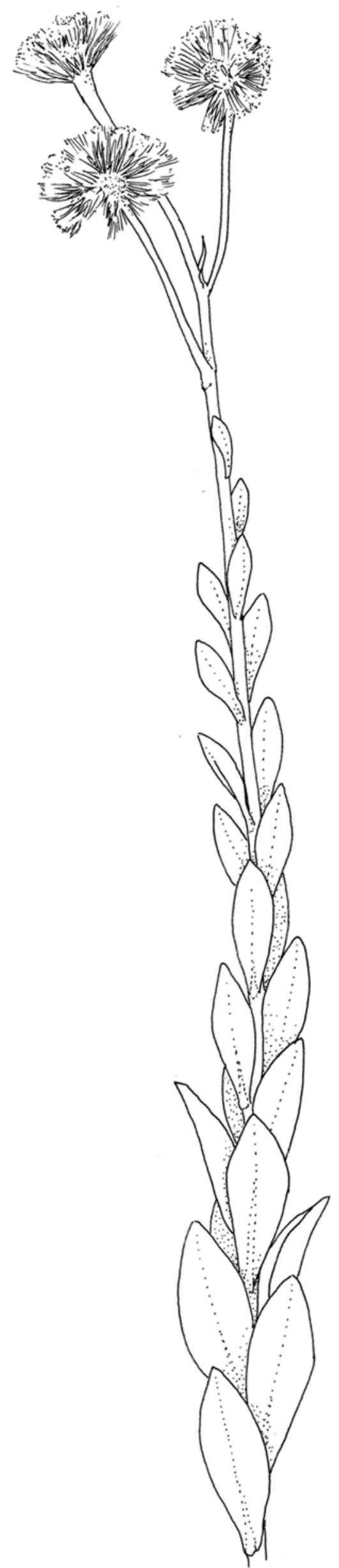




\section{AGRADECIMENTOS}

Ao contrário do que possa parecer, o trabalho científico não é feito solitariamente, e um doutorado é fruto do trabalho de muitas mãos e mentes.

Inicialmente, gostaria de agradecer as instituições que me ampararam durante o doutorado: o Instituto de Biociências da Universidade de São Paulo, onde a maior parte do trabalho foi executada, e o Department of Biological Sciences at the University of Memphis, onde todo o trabalho laboratorial foi conduzido, a Fundação de Amparo à Pesquisa do Estado de São Paulo (FAPESP) pelas duas bolsas que permitiram a condução desse trabalho (2013/18189-2 and 2016/12446-1).

Durante esse período eu também recebi financiamento de outras instituições, que permitiram que eu viajasse para conferências e consultas a herbários, e devem ser reconhecidas aqui: The Smithsonian Institution, pelo Cuatrecasas Fellowship Award, que permitiu que eu viajasse aos EUA para consultar coleções de herbários e que me abriu muitas portas, American Society of Plant Taxonomists pelo prêmio de viagem para o Botany 2017, Association of Southeastern Biologists pelo prêmio de viagem para que eu participasse do seu encontro anual em 2017 e pelo prêmio de melhor pôster em Botânica, Botanical Society of America pelo prêmio de melhor pôster em Botânica no encontro da ASB de 2017 e também pelo prêmio Triarch de fotografia no Botany 2017.

As primeiras pessoas que tenho que agradecer são meus pais, Cíntia e Roberto, que sempre me estimularam a continuar com a minha formação e me apoiaram em mais formas do que eu consigo enumerar. Muito obrigada e espero que vejam essa tese como uma realização sua também.

O mesmo vale para meu parceiro, Luiz, que sempre esteve ao meu lado durante todo esse tempo, mesmo à distância e nos momentos difíceis. Ter seu apoio e compreensão foram fundamentais para chegar até aqui e espero que você veja essa tese como uma vitória sua também. E também todas as vezes quando você me trouxe água quando eu estava perdida no trabalho. Te amo.

A contribuição do meu orientador, Pirani, também foi essencial para que o trabalho alcançasse o nível em que chegou, sempre me estimulando para pensar além da minha conclusão inicial e sempre dando ótimas sugestões. Foi um prazer ter sido sua aluna durante a iniciação científica, o mestrado e o doutorado e espero continuar essa parceria no futuro.

Ao meu co-orientador e amigo, Benoit Loeuille, por ter inicialmente sugerido o projeto e ajudado ele a tomar o rumo que tomou, sempre me dando ideias novas e sugerindo métodos diferentes. Obrigada também pelas leituras críticas (às vezes até demais) e por ter me auxiliado a navegar o mundo das submissões e publicações científicas. Que essa parceria continue e renda muitos frutos!

Tenho que agradecer minha supervisora no exterior, Dra. Jennifer Mandel, que se tornou uma segunda orientadora e me acolheu nos EUA como se eu fosse um de seus alunos, confiando em mim e me dando muitas responsabilidades. Esse período foi essencial para que eu aprendesse como um laboratório realmente funciona, e sem a sua colaboração esse trabalho seria muito diferente e provavelmente não tão rico.

Gostaria também de agradecer a Vicky Funk, por ter me recebido em Washington, D.C. e por ter me apresentado à Jennifer, efetivamente possibilitando que esse trabalho fosse feito e depois me convidando para participar em outros projetos e confiando no meu trabalho.

Devo agradecer meus amigos sinanterólogos, Benoit Loeuille, Gustavo Heiden e Caetano Oliveira que me apresentaram às plantas em diversos trabalhos de campo e também na convivência do dia a dia. Muito obrigada por sempre estarem abertos às minhas dúvidas e por terem tornado esse tempo mais divertido. 
A todos que foram a campo comigo, meu mais sincero obrigada, sem vocês esse trabalho não existiria: Benoit Loeuille, Gustavo Heiden, Caetano Oliveira, Kioshi Beraldo, Lúcia Moura, Irenice Gomes, Annelise Frazão, João de Deus Vidal, Daniela Bicudo, Didier Poumayrac, Nívea Pinheiro, Rodolph Sartin, Maria Elvira Martucci, Profa. Silvana Ferreira e alunos, Mateus Cota, Paulo Gonella, Maurício Watanabe, João Bringel e Prof. José Siqueira e a equipe do CRAD.

Todos os colegas do Sobre-as-Ondas, presentes e passados, que também contribuíram para esse trabalho: Annelise Frazão, Leonardo Borges, Cíntia Luiza Luz, Juliana El Ottra, Augusto Giaretta, Carolina Agostini, Eric Kataoka, Gisele Alves, Guilherme Antar, Jennifer Carvalho, Juliana Rando, Juliana Lovo, Luiz Henrique Fonseca, Marcelo Devecchi, Matheus Cota, Maurício Watanabe, Pamela Santana, Rebeca Viana, Paulo Baleeiro, Pedro Fiaschi, Mariana Wagner, Matheus Santos, Eduardo Leal, Maila Beyer, Jéssica Francisco, Beatriz Gomes. Agradeço especialmente à Carol Andrino, companheira de vitórias e frustrações, Paulo Gonella, sempre presente, e Marcelo Kubo, por segurar todas as pontas quando eu mais preciso.

Aos técnicos do Herbário SPF, pelo incansável trabalho para manter a coleção ativa: Vivi Jono, Roberta Figueiredo e Abel Cangussu. Aos outros professores do Laboratório de Sistemática Vegetal: Lúcia Lohmann, Paulo Sano e Renato Mello-Silva.

Aos Profs. João Semir, Samantha Koehler e Paulo Sano, que participaram da banca de qualificação e deram sugestões valiosas.

Aos amigos e colegas de Memphis, por terem tornado meu tempo fora mais agradável e também mais produtivo: Mike Ballou, Darrell Brandon, Adam Ramsey, Ram Thapa, Kendall Major, Nathaniel Praher, Gabbie Johnson, Malle Carrasco-Harris.

Também, aos meus amigos de todas as horas, Maysa Miceno, Bruno Motta, Lucila Barreiros, Luque Pilar Saraiva, Henrique Kurosaki, muito obrigada por estarem sempre presentes!

Muito obrigada!! 


\section{ACKNOWLEDGMENTS}

Scientific work is never done solo, and the effort to get a $\mathrm{PhD}$ is actually done by many minds and hands.

I would like to thank all institutions that supported me in material and financial ways during this period: Instituto de Biociências da Universidade de São Paulo, where most of the work was carried out, the Department of Biological Sciences at the University of Memphis, where all the lab work was conducted, FAPESP (Fundação de Amparo à Pesquisa do Estado de São Paulo) for the two scholarships that that allowed me to carry this work out (2013/18189-2 and 2016/12446-1).

During this period, I received funding from other institutions that allowed me to travel for conferences and should be acknowledged here: The Smithsonian Institution, for the Cuatrecasas Fellowship Award, which allowed me to study the collections in the USA herbaria, the American Society of Plant Taxonomists for the travel award that took me to Botany 2017, the Association of Southeastern Biologists for a travel award that allowed me to go to its meeting in 2017 and for the award for Best Poster in Botany and the Botanical Society of America for the award for Best Poster in Botany at the ASB 2017 meeting and also for the Triarch photo award at Botany 2017.

I would like to thank Dr. Jennifer Mandel, for receiving me in Memphis as if I were one of her own students, for always being so attentive, answering the thousands of questions I had every day, helping me at the lab and giving the opportunity to train other students and also for the opportunity to work in other projects and learn new things. I hope we keep on working together in the future!

Dr. Vicky Funk was fundamental in my personal development as a student, as she introduced me to Dr. Mandel and also opened a lot of doors for me. Thank you so much for being an inspiration for present and future generations of synantherologists.

I had much help at the University of Memphis to deal with the bureaucracy of moving to another country and getting things started. I would like the thank Zach Ramsey, for always taking the time to help me with stuff, Dr. Randall Bayer, and John Ryall, for helping with my visa.

I want to give a huge thanks to my friends and colleagues from the Mandel Lab and the Department of Biological Sciences, Mike Ballou, Darrell Brandon, Adam Ramsey, Ram Thapa, Kendall Major, Nathaniel Praher, Gabbie Johnson and Malle Carrasco-Harris. Y'all made my life more interesting while I was at Memphis, and I also learned a lot from you (especially about mitochondria) with every talk, paper discussion and comments. I hope I also made your life more interesting when I was around and contributed to your own works as well.

Thank you so much, y’all!! 


\section{TABLE OF CONTENTS}

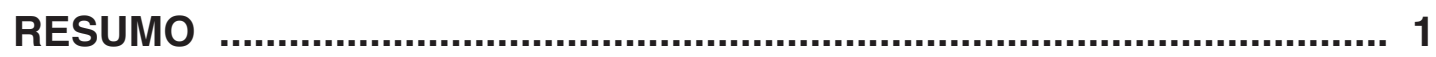

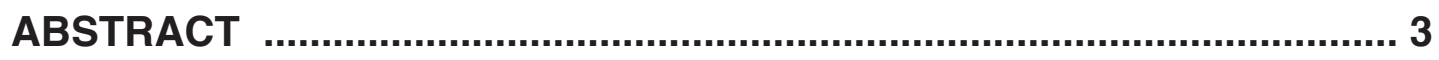

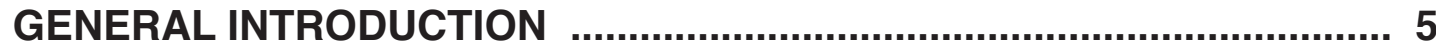

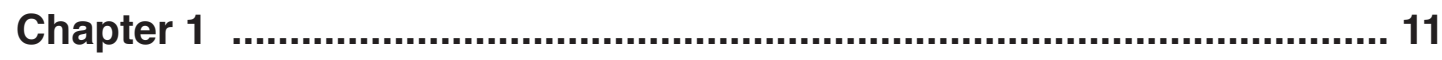

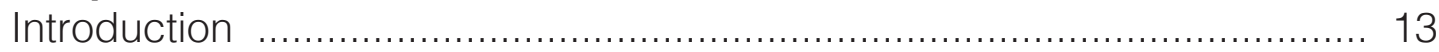

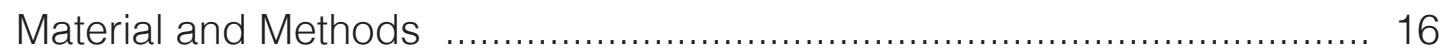

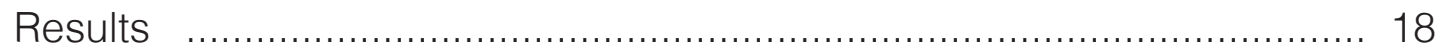

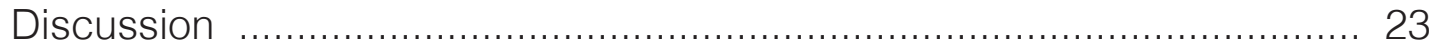

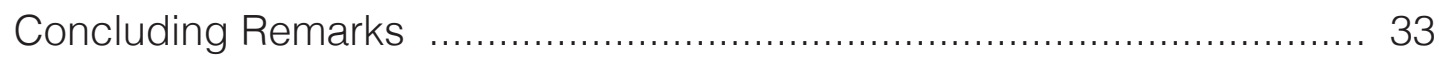

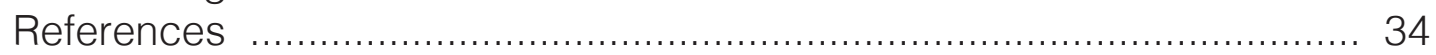

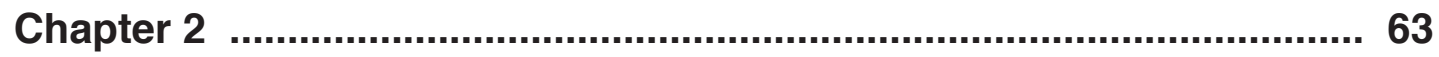

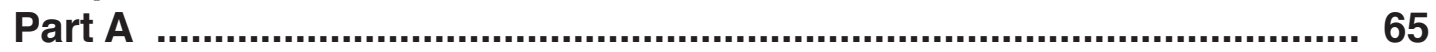

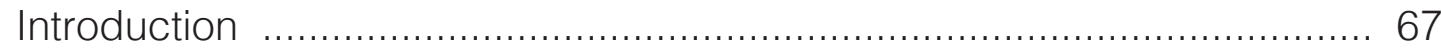

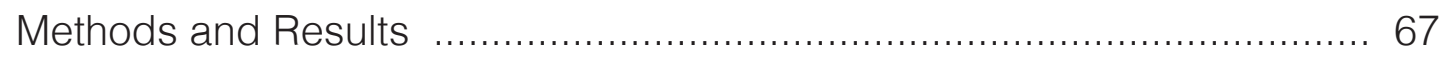

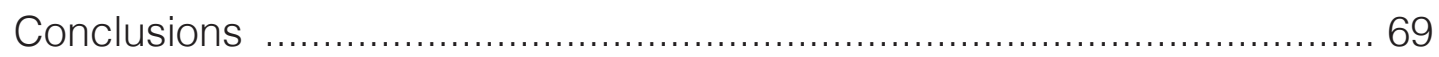

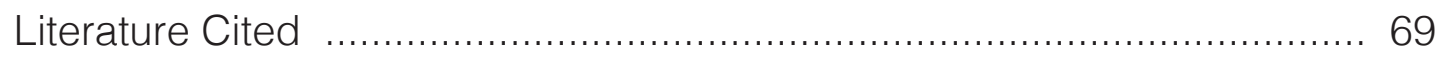

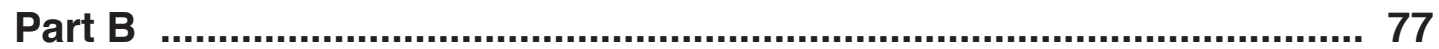

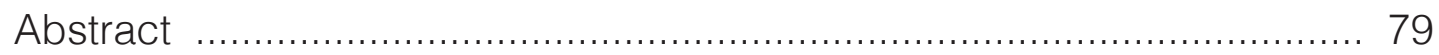

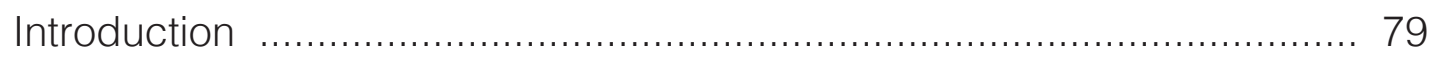

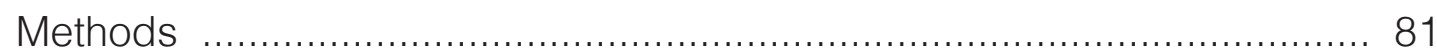

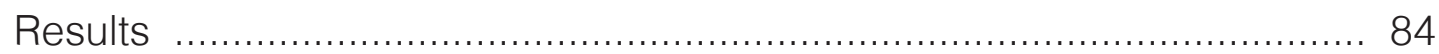

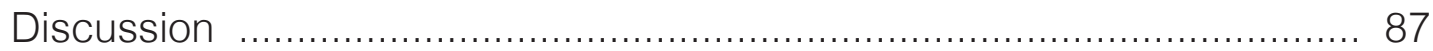

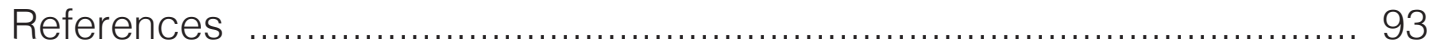

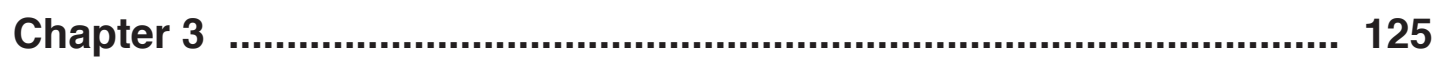

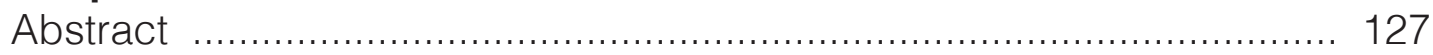

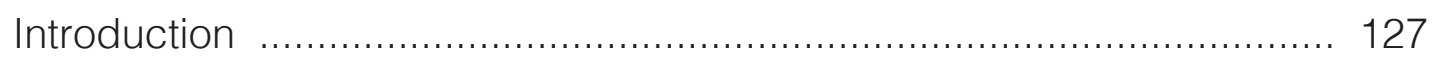

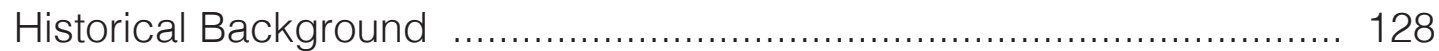

Novel infrageneric classification ……............................................ 131

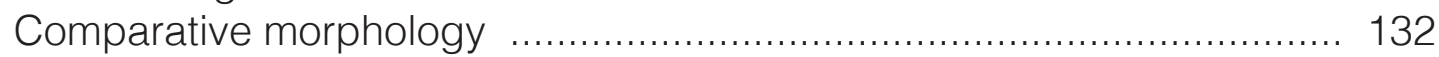

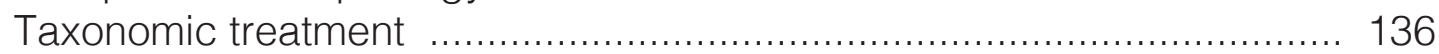

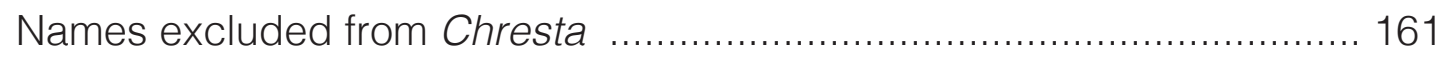

Numerical list of accepted species …............................................ 161

Index to scientific names in Chresta .............................................. 162

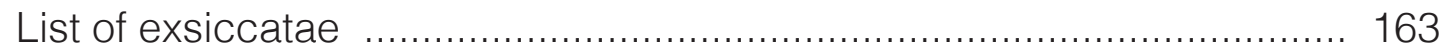

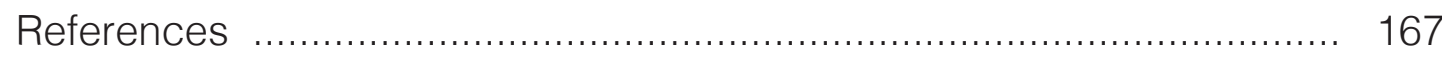

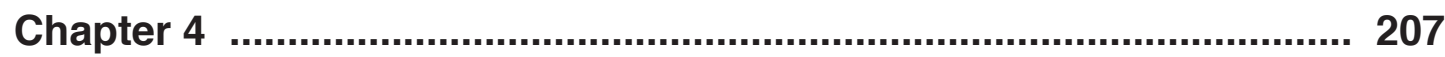

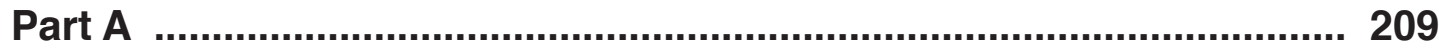

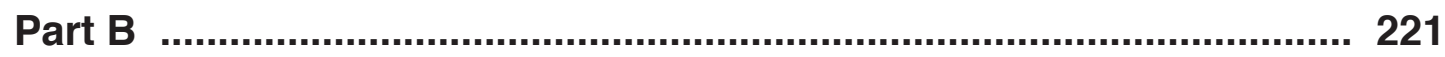

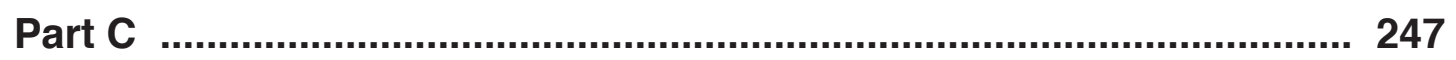

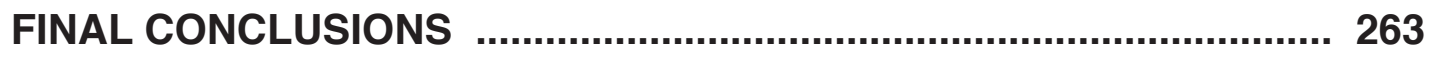

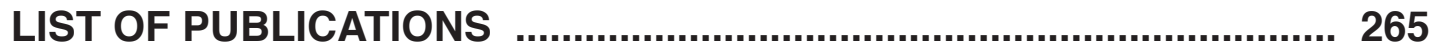




\section{LIST OF TABLES}

\section{Chapter 1}

Table 1

Table 2

\section{Chapter 2}

\section{Part A}

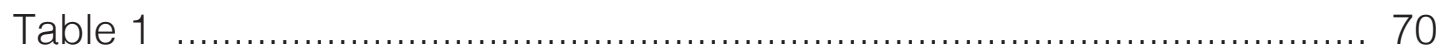

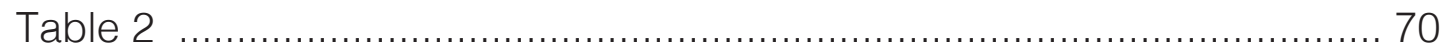

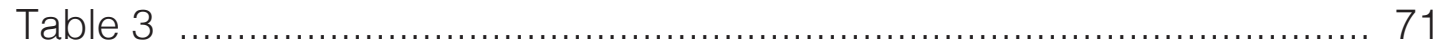

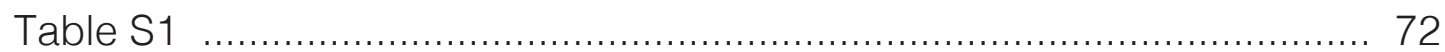

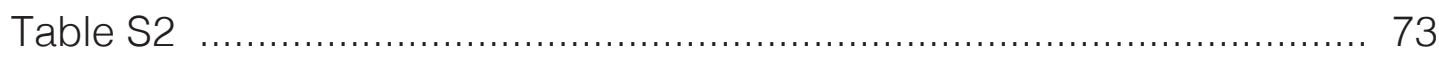

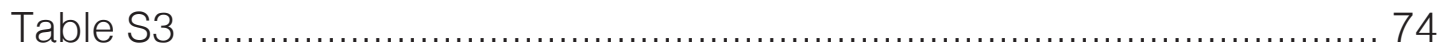

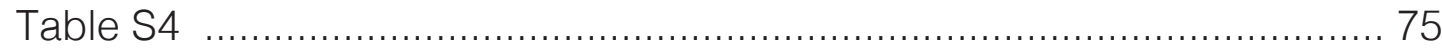

Part B

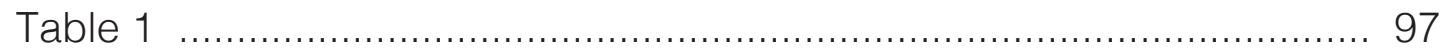

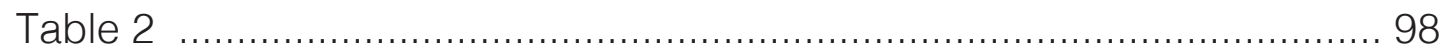

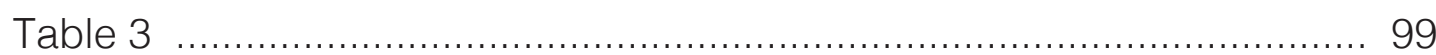

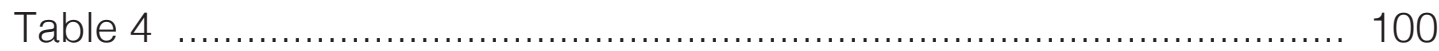

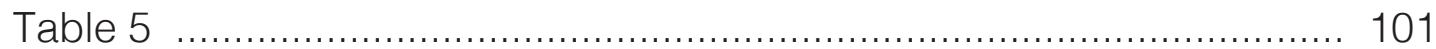

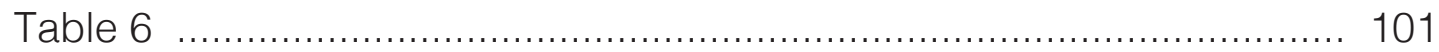

\section{Chapter 4}

\section{Part B}

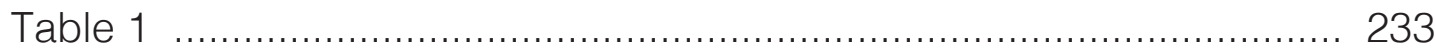

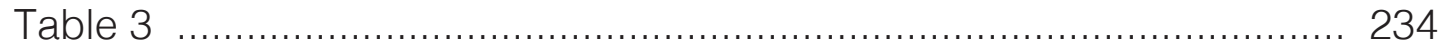

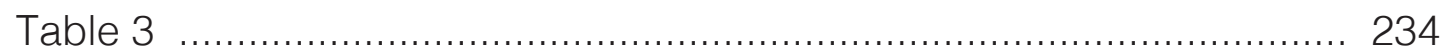

\section{LIST OF FIGURES}

\section{Chapter 1}

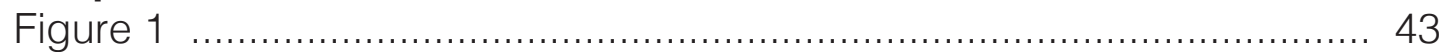

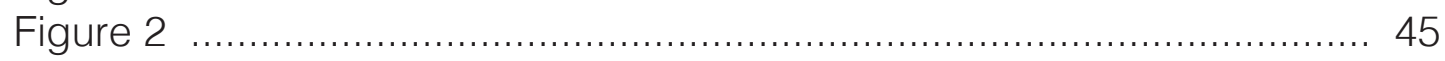

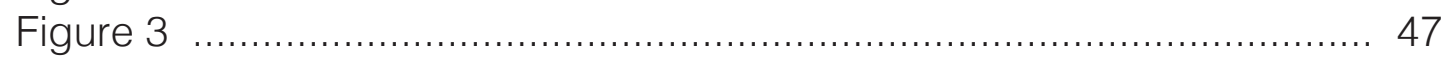

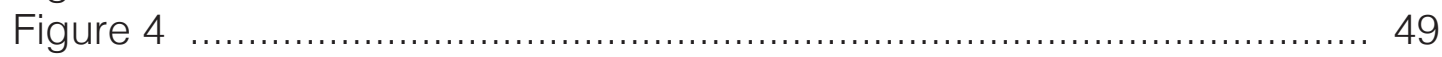

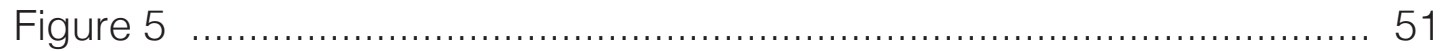

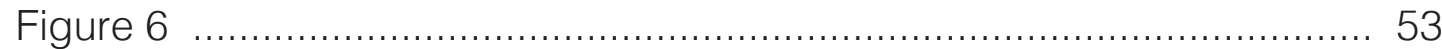

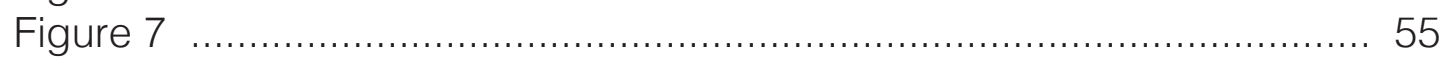

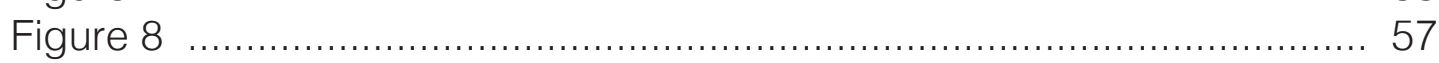

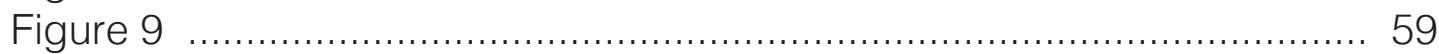

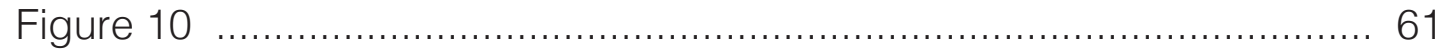

\section{Chapter 2}

\section{Part B}

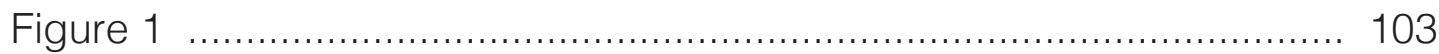

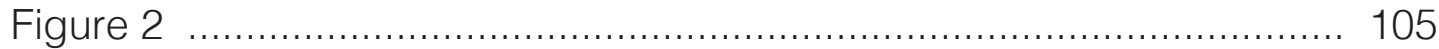

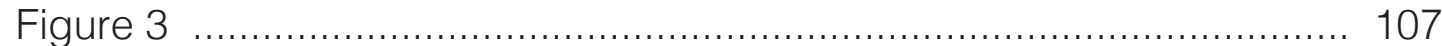

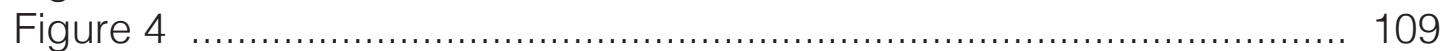

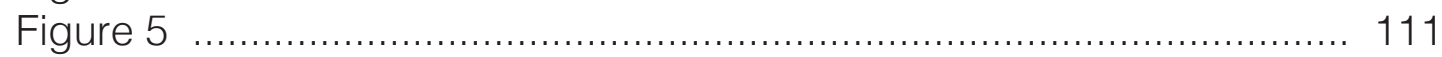

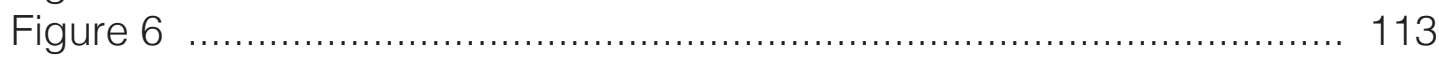

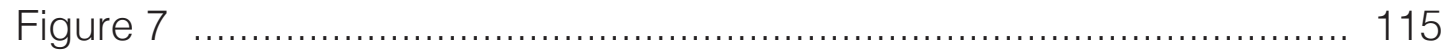


Figure 8

Figure 9

Figure 10

Figure 11

\section{Chapter 3}

Figure 1 169

Figure 2 171

Figure 3 173

Figure 4 175

Figure 5 177

Figure 6 179

Figure 7 181

Figure 8 183

Figure 9 185

Figure 10 187

Figure 11

Figure 12 189

Figure 13 191

Figure 14 193 195

Figure 15 197

Figure 16 199

Figure 17 201

Figure 18 203

Figure 19 205

\section{Chapter 4}

\section{Part A}

Figure 1 213

Figure 2 214

Figure 3 215

Figure 4 217

\section{Part B}

Figure 1 235

Figure 2 237

Figure 3 239

Figure 4 241

Figure 5 243

Figure 6 245

\section{Part C}

Figure 1 255

Figure 2 257

Figure 3 259 
Chresta pertence à tribo Vernonieae e apresenta dezoito espécies distribuídas nos domínios da Caatinga, Cerrado e Mata Atlântica. A extensa variabilidade de caracteres observada no gênero fez com que suas espécies fossem atribuídas a diversos gêneros distintos e até mesmo classificadas em diferentes grupos dentro da tribo. Tentativas anteriores de definir a posição do gênero em relação a outras subtribos de Vernonieae não foram bem-sucedidas. Nesse trabalho, apresentamos uma nova filogenia para Chresta, baseada numa amostragem taxonômica completa da qual obtivemos centenas de marcadores moleculares e, pela primeira vez, métodos filogenômicos são aplicados a um grupo neotropical de Asteraceae. Essa análise confirma a monofilia de Chresta, resolve as relações infragenéricas com alto suporte, e define com sucesso o grupo-irmão do gênero, embora as relações dessa linhagem com Lychnophorinae e Lepidaploinae ainda sejam duvidosas. Usamos as árvores obtidas para reconstruir estados ancestrais de dez caracteres morfológicos selecionados face a sua provável relevância na história do grupo, e assim propomos um cenário biogeográfico no qual a diversificação do grupo pode ter ocorrido. Também usamos marcadores de microssatélites para estudar a genética de populações de cinco espécies da Caatinga que apresentam populações naturalmente isoladas, devido a sua restrição a afloramentos rochosos de área limitada. Essas espécies apresentam diferentes padrões, variando no grau de diversidade e estruturação genética. Esses dados permitem uma discussão do impacto relativo de fatores como distância espacial, preferência de substrato, tamanho populacional e capacidade de dispersão, sobre o fluxo gênico entre as populações analisadas. Também apresentamos uma sinopse ilustrada do gênero, com uma nova classificação infra-genérica filogenética, condensando o conhecimento acumulado até o momento sobre Chresta. A sinopse inclui descrição de quatro espécies novas, chave de identificação das 18 espécies aceitas e três táxons infragenéricos, sinonímia completa, ilustrações e mapas de distribuição das espécies, bem como seu status de conservação atual.

Palavras-chave: Chrestinae, Compositae, filogenia, genética de populações, sinopse. 


\section{ABSTRACT}

Chresta belongs to tribe Vernonieae, subtribe Chrestinae, and presents eighteen species distributed in the Caatinga, Cerrado and Mata Atlântica domains. Its species display a fairly wide range of characters that led the species to be ascribed to several distinct genera, sometimes also classified into different groups inside the tribe. Attempts to define the position of the genus in relation to other Vernonieae subtribes and to understand the relationships within the genus have so far been unsuccessful. In this work, we present a novel phylogeny for Chresta, based on a complete set of sampled taxa from which hundreds of molecular markers were assessed, and for the first time, phylogenomics methods are applied to a Neotropical group of Asteraceae. We confirm the monophyly of Chresta and resolve infrageneric relationships with high support for all clades. We also successfully define the sister group to the genus, although the relations of this whole lineage with Lychnophorinae and Lepidaploinae are still doubtful, and. We use the obtained trees to reconstruct ancestral states of ten selected characters, which seem to have played an important role during the history of the genus, and propose a biogeographical scenario where the diversification of the group may have taken place. We also use evidence from microsatellite markers to study the population genetics of five species from the Caatinga that naturally present isolated populations restricted to narrow rupiculous habitats. These species present contrasting patterns, varying in their degree of genetic diversity and structuring, and this data enable us to discuss the relative impact of factors such as spatial distance, substrate preference, population size and dispersal ability on the genetic flow among the populations assessed. We also present an illustrated synopsis of the genus, with a new phylogenetic infrageneric classification, summarizing the accumulated knowledge about Chresta so far. We provide descriptions of four new species, a key for identification of 18 accepted species and three infrageneric taxa, synonyms, illustrations and distribution maps of the species, as well as their current conservation status.

Keywords: Chrestinae, Compositae, phylogeny, population genetics, synopsis. 


\section{GENERAL INTRODUCTION}

Asteraceae (or Compositae) is one of the largest families of Angiosperms, with around 24,000 species and ca. 1700 genera ( $10 \%$ of all spermatophytes), distributed in the whole world, except for Antarctica (Funk et al. 2009). Peculiar characters of the family, such as flowers organized in capitula, the fused anthers, the secondary pollen presentation and fruits of the type cypsela with pappus, have contributed to it being acknowledged as natural group since the Middle Age (Small 1919); its monophyly was posteriorly confirmed in several molecular and morphologic phylogenetic analysis (e.g. Jansen \& Palmer 1987, Lundberg \& Bremer 2003; Keeley \& Robinson 2009). Around 2000 species are found in Brazil, 65\% of which are endemic to this country (Brazil Flora Group 2015).

The family is currently subdivided in 12 subfamilies and 28 tribes (Panero \& Funk 2002), with Vernonieae being one of the largest tribes, with $\sim 129$ genera e 1100 espécies (Keeley \& Robinson 2009). Vernonieae was initially delimited by Cassini (1816), based on several characters, including the dorsally curved style arms that are common in the group (Cassini 1819), with the general delimitation being sparsely changed since then. The monophyly of Vernonieae was corroborated in several phylogenetic analyses (e.g. Keeley \& Jansen 1991, 1994; Kim \& Jansen 1995; Kim et al. 1998; Keeley et al. 2007) and the tribe is currently placed in subfamily Cichorioideae. Recently analysis using large genomic datasets, however, put the monophyly of Cichorioideae in doubt (Mandel et al. 2017), indicating that relationships in that part of the family might not be as stable as it was once thought.

Besides the presence of thin styles, with filiform and pilose arms, other important features of tribe Vernonieae are the variety of habits, from herbs to trees, the phylotaxy that is usually alternate and the discoid, homogamous capitula that usually present purple, lilac or white florets (Keeley \& Robinson 2009). One remarkable feature is the widespread presence of secondary heads (i.e. syncephalia) in the tribe, which occur in ca. 14 genera, mostly from the New World (Loeuille et al. 2015a); this character has been historically used to further divide the tribe into subtribes (e.g. Baker 1873). Vernonieae is found in the American continent, in Africa and Asia, and the main diversity centers are Brazil and Africa. Members of the tribe show a peculiar tolerance for soils with unusual composition, such as those with high contents of iron, bauxite and dolomite (Keeley \& Robinson 2009). In Brazil, the tribe is especially representative in the Cerrado phytogeographical domain, where many species occupy the campos rupestres, an herbaceous and shrubby type of vegetation found in high elevations, in sandy and rocky soils (Loeuille et al 2015a, b).

Among the Brazilian taxa is Chresta, composed by 18 species of herbs, subshrubs and shrubs distributed in the Caatinga, Cerrado and Atlantic Forest. Species of the genus are frequently found in rock outcrops and other types of dry and rocky soils. Some of the features that define Chresta are the presence of syncephalia, which can have different morphologies, the indument composed of T-shaped trichomes, the non-sclerified cells on the anther appendages, pappus composed of several series of setose elements and a variety of underground systems.

The first phylogenetic studies in Vernonieae were mainly focused on the monophyly and composition of the mega-genus Vernonia, which grouped ca. 1000 species, until its dismemberment after several taxonomic (several treatments by Robinson, but specially 1999a, b, c) and phylogenetic works (Kim \& Jansen 1995, Keeley\& Turner 1990, Keeley et al. 2007), resulting in many monotypic and small genera and a new circumscription for Vernonia, containing ca. 20 species (Keeley \& 
Robinson 2009). More recently, phylogenetic studies were used to investigate the origin of syncephaly in the American taxa of tribe (Loeuille et al. 2015a) and also to understand the relationships within Lychnophorinae, one of the most representative subtribes in Brazil (Loeuille et al. 2015b). These more recent study helped clarify many of the relationships within South American taxa, but still left some unresolved issues, mainly due to poor resolution and support.

Chresta was sampled in two previous phylogenies (Keeley et al. 2007, Loeuille et al. 2015a), which showed the genus to be monophyletic, but placed doubt about its relationships with other Vernonieae subtribe, mainly Lychnophorinae and Vernoniinae. The relationships within the genus showed the presence of two clades, one with Caatinga species and other with Cerrado species, but the internal resolution was not enough to draw conclusions about morphological evolution within the genus.

Molecular phylogenetic studies in Asteraceae have been challenging, mainly due to the abundant polyploidization in the family, both ancient and current, what makes the identification of orthologous nuclear markers difficult (Badouin et al. 2017, Mandel et al. 2017). Besides, the chloroplast genome (plastome) in the family has been shown to be highly conserved at the sequence level, reducing its usefulness in studies of closely related taxa (Shaw et al. 2005, Timmee et al. 2007).

The advances on sequencing techniques in the last two decades (Mardis 2008), with the development of parallel, high-throughput sequencing (Delseny et al. 2010), has been seen as promising to tackle these types of issues (Bräutigam \& Gowik 2010), using different approaches, like shotgun sequencing, RADseq (Davey \& Blaxter 2010), and Hyb-Seq (Weitemeier et al. 2014) for different types of data. Methods that combine targeting of specific genomic regions with large-scale sequencing are the most promising methods for phylogenetic studies, as they allow the sequencing of hundreds of markers at once and use DNA as source, instead of RNA, as in transcriptome sequencing. On the other hand, they require previous information about the regions of interest, such as a reference genome or EST database. A set of probes based on sunflower ESTs has been developed to be used across the Asteraceae (Mandel et al. 2014), with promising results (Mandel et al. 2015, 2017).

Whereas phylogenies allow the study of the genus as a whole, having species as terminals of the analysis, when this morphological variation is observed among members of a same species, studies focusing on population genetics and phylogeography are more informative. Field observations and study of herbarium collections have evidenced interesting cases of infraspecific variation in the group of Chresta species from the Brazilian Caatinga.

Chresta artemisiifolia, C. harleyi H.Rob., C. hatschbachii H.Rob. and C. subverticillata all occur in a short stretch of Espinhaço Septentrional and Chapada Diamantina (Alkmim 2012), where they form distinct populations delimited by the rock outcrops where they occur. These four species are morphologically similar, what raises interesting questions about the patterns of occupation and speciation in fragmentary rocky environments in the Caatinga.

Chresta martii (DC.) H.Rob. has a wider distribution, forming three geographic clusters around the Northern portion of Rio São Francisco. The geographic clusters are very isolated from each other, and there are some morphological differences between populations in each one of them, with plants on the western portion of the distribution being robust, profusely ramified, with wide leaves, while the plants on the eastern end are smaller, with less ramifications and more delicate, narrower leaves. This geographical separation associated to morphological differentiation is an interesting setting to study effects of gene flow and reproductive isolation in natural populations. 
This has implications for conservation, as small, isolated populations often show strong population structuring, with little genetic variation among members of a given population, but with some variation among members of different populations (Gitzendanner \& Soltis 2000). Regarding Chresta species from the Caatinga, the majority of their populations are outside of conservation units, sometimes presenting scarce populations, each with a restricted number of individuals, practically isolated from other populations of the same species, posing a challenge to their conservation.

Phylogenomics datasets have been used in the past few years as a source for microsatellite mining, as they usually present large portions of coding and non-coding portions of the genome, facilitating the process of developing and validating these markers (Jennings et al. 2011). Computational resources can be used to identify putative repetitive regions, even allowing the comparison with homologous sequences from other species, thus contributing to the development of microsatellite markers transferable among different species, which is an advance to studies comparing multiple species. Even though the advances in sequencing have brought over new methods to study populations, like RADSeq and Pool-Seq (Schlötterer et al. 2014), microsatellites are still widely used, proving to be valuable resources in several types of population studies (Hodel et al. 2016).

In face of the accumulated knowledge about Chresta, and with the possibility of applying new methods and new approaches to study the relationships of the genus with other Vernonieae subtribes, as well as the intraspecific relations within the genus, this work proposed to study the systematics and evolution of Chresta and summarize the current knowledge about its species. The results of each study are organized in the following chapters:

Chapter 1 presents a new phylogenetic hypothesis for Chresta, reevaluating the relationships within Vernonieae, focusing on other representative Brazilian taxa. The target capture method developed by Mandel et al. (2014) was used to obtain a molecular matrix composed by ca. 700 nuclear markers, which provided complete resolution and good support for almost all nodes. The resulting tree was used to study morphological evolution in the genus, through mapping of different character states. The phylogeny was also used to propose a biogeographical scenario explaining the occupation of the Caatinga and Cerrado by the genus. This part of the study was conducted in partnership with the Mandel Lab at the University of Memphis, TN, USA, and will be co-authored by Dr. Benoit Loeuille, Dr. Jennifer Mandel and Dr. José R. Pirani.

Chapter 2 is divided in two parts; Part A contains the process of developing and validating microsatellite markers transferable among species of Chresta from the Caatinga, which will be coauthored by Dr. José R. Pirani and Dr. Jennifer Mandel. Part B presents a population genetics study of five Caatinga species, focusing on genetic diversity and structuring among populations of these species, aiming to understand what processes are at play on the speciation in this group. This part will be co-authored by Dr. Benoit Loeuille, Dr. José R. Pirani and Dr. Jennifer Mandel. This chapter is also a product of the partnership with the University of Memphis.

Chapter 3 summarizes all the taxonomic and systematics knowledge of the genus in a synopsis, also proposing a new infra-generic classification. The synopsis is also an attempt to standardize the nomenclature within the genus, as no comprehensive treatments have been published since the 1980s, when it was split into five different taxa, and because new species and synonyms were published in the last two decades. This chapter also presents illustrations of species that were not previously illustrated, as well as maps and photographs, and also evaluation of conservation status for all species. It will be co- 
authored by Marcelo T. Kubo, Dr. Benoit Loeuille and Dr. José R. Pirani.

Chapter 4 is divided in three parts and presents four new species of Chresta. Part A contains a paper already published in the period Phytotaxa (Siniscalchi et al. 2016), describing C. filicifolia, the only species endemic to the Atlantic Forest in the genus. Part B contains a work that is already submitted at Systematic Botany, containing two new species of the Caatinga. Part C contains another paper that will be submitted to Phytotaxa, describing a new species from Bahia, fruit of a partnership with researchers from the herbarium HVASF, in Petrolina, Pernambuco.

\section{References}

Alkmim, F.F. 2012. Serra do Espinhaço e Chapada Diamantina. Pp. 236-244 In: Geologia do Brasil, Eds: Hasui, Y., Carneiro, C.D.R., Almeida, F.F.M. \& Bartorelli, A., Beca, São Paulo, Brasil.

Badouin, H. et al. 2017. The sunflower genome provides insights into oil metabolism, flowering and Asterid evolution. Nature 546(7656): 148-152.

Baker, J.G. 1873. Compositae I. Vernoniaceae. Pp. 5-180 In Flora brasiliensis, 6(2), eds C. F. P. von Martius † and A. W. Eichler, Fried. Fleischer, Münich, Vienna, Leipzig.

Bräutigam, A. \& Gowik, U. 2010. What can next generation sequencing do for you? Next generation sequencing as a valuable tool in plant research. Plant Biology 12: 831-841.

Brazil Flora Group. 2015. Growing knowledge: an overview of Seed Plant diversity in Brazil. Rodriguésia 66(4): $1085-1113$.

Cassini, H. 1816. Troisième mémoire sur les Synanthérées. Journal de Physique, de Chimie, d'Histoire Naturelle et des Arts 82: 116-146.

Cassini, H. 1819. Suite de Sixième mémoire sur la famille des Synanthérées contenant des caractères des tribus. Journal de Physique, de Chimie, d'Histoire Naturelle et des Arts 88: 189-204.

Davey, J.W. \& Blaxter, M.L. 2010. RADSeq: next-generation population genetics. Briefings in Functional Genomics 9(5-6): 416-423.

Delseny, M., Han, B. \& Hsing, Y.I. 2010. High throughput DNA sequencing: The new sequencing revolution. Plant Science 179: 407-422.

Funk, V.A., Susanna, A., Stuessy, T.F. \& Bayer, R.J. 2009. Systematics, evolution and biogeography of Compositae. Vienna, Austria: International Association for Plant Taxonomy (IAPT).

Gitzendanner, M.A. \& Soltis, P.S. 2000. Patterns of genetic variation in rare and widespread plant congeners. American Journal of Botany 87(6): 783-792.

Hodel, R.G.J., Segovia-Salcedo, M.C., Landis, J.B., Crowl, A.A., Sun, M., Liu, X., Gitzendanner, M.A., Douglas, N.A., Germain-Aubrey, C.C., Chen, S., Soltis, D.E. \& Soltis, P.S. 2016. The report of my death was an exaggeration: a review for researchers using microsatellites in the $21^{\text {st }}$ century. Applications in Plant Sciences 4(6): 1600025.

Jansen, K. \& Palmer, J.D. 1987. A chloroplast DNA inversion marks an ancient evolutionary split in the sunflower family (Asteraceae). Proceedings of the National Academy of Sciences of the United States of America 84: 58185822.

Jennings, T.N., Knaus, B.J., Mullins, T.D., Haig, S.M. \& Cronn, R.C. 2011. Multiplexed microsatellite recovery using massively parallel sequencing. Molecular Ecology Resources 11: 1060-1067.

Keeley, S.C. \& Turner, B.L. 1990. A preliminary cladistic analysis of the genus Vernonia (Vernonieae: Asteraceae). Plant Systematics and Evolution, Supplementum 4: 45-66.

Keeley, S.C. \& Jansen, K. 1991. Evidence from chloroplast DNA for the recognition of a new tribe, the Tarchonantheae, and the tribal placement of Pluchea (Asteraceae). Systematic Botany 16: 173-181.

Keeley, S.C., Forsman, H.Z. \& Chan, R. 2007. A phylogeny of the "evil tribe" (Vernonieae: Compositae) reveals Old/ New World long distance dispersal: support from separate and combined congruent datasets (trnL-F, ndhF, ITS). Molecular Phylogenetics and Evolution 44: 89-103.

Keeley, S.C. \& Robinson, H. 2009. Vernonieae. In: Systematics, Evolution, and Biogeography of Compositae. Eds: Funk, V.A., Susanna, A., Stussey, T.F. \& Bayer, R.J. Vienna, Austria: International Association for Plant Taxonomy 
(IAPT). Pp. 439-469.

Kim, K.-J. \& Jansen, K. 1995. $n d h F$ sequence evolution and the major clades in the sunflower family. Proceedings of the National Academy of Sciences of the United States of America 92: 10379-10383.

Kim, H.-G., Keeley, S.C., Vroom, P.S. \& Jansen, K. 1998. Molecular evidence for an African origin of the Hawaiian endemic Hesperomannia (Asteraceae). Proceedings of the National Academy of Sciences of the United States of America 95: 15440-15445.

Loeuille, B., Keeley, S.C. \& Pirani, J.R. 2015a. Systematics and evolution of syncephaly in American Vernonieae (Asteraceae) with emphasis on the Brazilian subtribe Lychnophorinae. Systematic Botany 40 (1): 286-298.

Loeuille, B., Semir, J., Lohmann, L.G. \& Pirani, J.R. 2015b. A phylogenetic analysis of Lychnophorinae (Asteraceae: Vernonieae) based on molecular and morphological data. Systematic Botany 40(1): 299-315.

Lundberg, J. \& Bremer, K. 2003. A phylogenetic study of the order Asterales using one morphological and three molecular data sets. International Journal of Plant Sciences 164: 553-578.

Mandel, J.R., Dikow, R.B., Funk, V.A., Masalia, R.R., Evan Staton, S., Kozik, A., Michelmore, R.W., Rieseberg, L.H. \& Burke, J.M. 2014. A target enrichment method for gathering phylogenetic information from hundreds of loci: an example from the Compositae. Applications in Plant Sciences 2(2): 1-6.

Mandel, J.R., Dikow, R.B. \& Funk, V.A. 2015. Using phylogenomics to resolve mega-families: An example from Compositae. Journal of Systematics and Evolution 53(5): 391-402.

Mandel, J.R., Barker, M.S., Bayer, R.J., Dikow, R.B., Gao, T.G., Jones, K.E., Keeley, S., Kilian, N., Ma, H., Siniscalchi, C.M., Susanna, A., Thapa, R., Watson, L. \& Funk, V.A. 2017. The Compositae tree of life in the age of phylogenomics. Journal of Systematics and Evolution 55(4): 405-410.

Mardis, E.R. 2008. Next-Generation DNA sequencing methods. Annual Review of Genomics and Human Genetics 9: 387-402.

Panero, J.L. \& Funk, V.A. 2002. Toward a phylogenetic subfamilial classification for the Compositae (Asteraceae). Proceedings of the Biological Society of Washington 115: 909-922.

Robinson, H. 1999a. Generic and subtribal classification of American Vernonieae. Smithsonian Contributions to Botany 89.

Robinson, H. 1999b. Two new subtribes, Stokesiinae and Pacourininae, of the Vernonieae (Asteraceae). Proceedings of the Biological Society of Washington 112: 216-219.

Robinson, H. 1999c. Revisions in paleotropical Vernonieae (Asteraceae). Proceedings of the Biological Society of Washington 112: 220-247.

Schlötterer, C., Tobler, R., Kofler, R. \& Nolte, V. 2014. Sequencing pools of individuals - mining genome-wide polymorphism data without bid funding. Nature Reviews Genetics 15: 749-763.

Shaw, J., Lickey, E.B., Beck, J.T., Farmer, S.B., Liu, W., Miller, J., Siripun, K.C., Winder, C.T., Schilling, E.E. \& Small, R.L. 2005. The tortoise and the hare II: relative utility of 21 noncoding chloroplast DNA sequences for phylogenetic analysis. American Journal of Botany 92(1): 142-166.

Siniscalchi, C.M., Loeuille. B.F.P. \& Pirani, J.R. 2016. A new species of Chresta (Vernonieae, Asteraceae) endemic to the Mata Atlântica Domain, Brazil. Phytotaxa 244: 80-88.

Small, J. 1919. The origin and development of the Compositae. New Phytologist 18 (Reprint 11): 1-334 + pl. 1-6.

Timmee, R.E., Kuehl, J.V., Boore, J.L. \& Jansen, R.K. 2007. A comparative analysis of the Lactuca and Helianthus (Asteraceae) plastid genomes: identification of divergent regions and categorization of shared repeats. American Journal of Botany 94(3): 302-312.

Weitemeier, K., Straub, S.C.K., Cronn, R.C., Fishbein, M., Schmickl, R., McDonnell, A. \& Liston, A. 2014. Hyb-Seq: Combining target enrichment and genome skimming for plant phylogenomics. Applications in Plant Sciences 2(9): 1400042. 


\section{FINAL CONCLUSIONS}

In the last decades, phylogenetic studies have been used to study the evolution of morphological characters and biogeographical history of different groups, greatly increasing the knowledge about the current biodiversity and the evolutionary processes that acted on them. As one of the richest families of Angiosperms, Asteraceae is an important target for these studies, as the understanding of how this diversity came to be can also increase our knowledge about the diverse environments where they occur, and about how shifts in morphology can boost diversification.

The tribe Vernonieae is very diverse in Brazil, especially in drier environments, like the Cerrado, campos rupestres, rock outcrops and in the Caatinga. Chresta is a remarkable member of the tribe, found on the Caatinga, Cerrado and Mata Atlântica, presenting from widely distributed species like C. scapigera and C. sphaerocephala, to narrow endemics like C. hatschbachii and C. souzae. The morphological variety found in the group, expressed in different combinations of characters like leaf morphology, pattern of synflorescence branching, syncephalium morphology and growth, floret color and pollen type, has led to different interpretations of its taxonomy, with the species being kept in different genera (e.g. Candolle 1836, MacLeish 1984, 1985a, b) or united in the same genus (e.g. Gardner 1842, Baker 1873, Robinson 1999). The relationships of Chresta to other Vernonieae genera has also been a point of discussion, with the genus being grouped in the Lychnophorinae (e.g. Baker 1873) or as part of Vernonia (Lessing 1831) or even as a separate tribe (e.g. Robinson 1999), due to the unusual combination of characters like syncephalia, typical of Lychnophorinae, with the pollen type more commonly found in other Vernonieae. Previous phylogenies did not elucidate the position of Chresta in Vernonieae with certainty, due to a lack of resolution and support (e.g. Keeley et al. 2007, Loeuille 2015).

With the present study, we obtained a well resolved and supported phylogeny of Chresta, using Phylogenomics methods that provide hundreds of markers (Mandel et al. 2014), and used the phylogeny as a basis to study the evolution of the characters and biogeography in the genus. We verified that all taxonomic treatments that separated Chresta species in multiple genera relied in nonmonophyletic groupings, thus supporting Chresta as a single unit. Also, most of the characters used to divide these genera, like the ramification of the synflorescence or floret color, actually arose multiple times in the phylogeny or suffered reversals. Also, we recovered a biogeographical history depicting an early diversification of Chresta in the Caatinga area with posterior expansion into the adjacent Cerrado.

We also used five rupiculous, isolated and fragmentary species of Chresta from the Caatinga to study microevolutionary processes that may be underway in their populations, aiming to delineate general patterns of diversification. We found that although these species share several similarities in morphology and environmental requirements, they differ in their genetics, varying in the degree of isolation between populations and intensity of effects of genetic drift and inbreeding. These results have implications on conservation strategies for these species, as they may require different strategies to be protected.

In order to summarize the knowledge obtained during these studies, we also present an illustrated synopsis of the genus, proposing a new infrageneric classification based on the clades obtained in the phylogeny. We propose a wide circumscription for Chresta, containing eighteen species divided into two subgenera and three sections, defined by molecular synapomorphies and morphological 
characteristics.

With this study, we hope to contribute to the general knowledge of Asteraceae in Brazil and also to the understanding of the evolution and history of the plant biota of the phytogeographical domains that compose the Brazilian landscape. We also expect that our results will serve as a model for the incorporation of new methods and approaches to phylogenetic studies.

\section{References}

Baker, J.G. 1873. Compositae I. Vernoniaceae. Pp. 5-180 In Flora brasiliensis, 6(2), eds C. F. P. von Martius † and A. W. Eichler, Fried. Fleischer, Münich, Vienna, Leipzig.

Candolle, A. P. de. 1836. Vernoniaceae. Pp. 9-103 in Prodromus Systematis Naturalis Regni Vegetabilis, v. 5, Ed. A. P. de Candolle, Treutel et Würtz, Paris. Masson, Paris.

Gardner, G. 1842. Characters of three new species of Chresta. London Journal of Botany 1: 238-241.

Keeley, S.C., Forsman, Z.H. \& Chan, R. 2007. A phylogeny of the "evil tribe" (Vernonieae: Compositae) reveals Old/ New World long distance dispersal: Support from separate and combined congruent datasets (trnL-F, ndhF, ITS). Molecular Phylogenetics and Evolution 44(2007): 89-103.

Lessing, C.F. 1831. De Synanthereis dissertation quarta. Linnaea 6: 624-721.

Loeuille, B., Keeley, S.C. \& Pirani, J.R. 2015. Systematics and evolution of syncephaly in American Vernonieae (Asteraceae) with emphasis on the Brazilian subtribe Lychnophorinae. Systematic Botany 40 (1): 286-298.

MacLeish, N. F. F. 1984. Argyrovernonia and Paralychnophora: new names in the tribe Vernonieae (Asteraceae/ Compositae). Taxon 33: 105-106.

MacLeish, N.F.F. 1985a. Revision of Glaziovianthus (Compositae: Vernonieae). Systematic Botany 10: 347-352.

MacLeish, N.F.F. 1985b. Revision of Chresta and Pycnocephalum (Compositae: Vernonieae). Systematic Botany 10: 459-470.

Mandel, J.R., Dikow, R.B., Funk, V.A., Masalia, R.R., Evan Staton, S., Kozik, A., Michelmore, R.W., Rieseber, L.H. \& Burke, J.M. 2014. A target enrichment method for gathering phylogenetic information from hundreds of loci: an example from the Compositae. Applications in Plant Science 2(2): 1300085.

Robinson, H. 1999a. Generic and subtribal classification of American Vernonieae. Smithsonian Contributions to Botany 89. 116 pp. 


\section{List of publications}

Wagner, M.A., Loeuille, B.F.P., Siniscalchi, C.M., Melo-de-Pina, G.F. \& Pirani, J.R. 2014. Diversity of non-gandular trichomes in subtribe Lychnophorinae (Asteraceae: Vernonieae) and taxonomic implications. Plant Systematics and Evolution 300(5): 1219-1233.

Loeuille, B., Siniscalchi, C.M., Pirani, J.R., 2014. New names in Vernonieae (Asteraceae) of northeastern Brazil. Phytoneuron 2014-9: 1-11.

Siniscalchi, C.M., Loeuille, B.F.P., Pirani, J.R., 2016. A new species of Chresta (Vernonieae, Asteraceae) endemic to the Mata Atlântica Domain, Brazil. Phytotaxa 244(1): 80-88.

Siniscalchi, C.M., Loeuille B., Semir, J. \& Pirani, J.R. 2016. Lychnophora spiciformis (Asteraceae: Vernonieae), a new species from Bahia, Brazil. Phytotaxa 253(1): 48-56.

Siniscalchi, C.M., Souza-Souza, R.M.B., Loeuille, B., Pirani, J.R. \& Gonçalves-Esteves, V. 2017. The systematic value of pollen morphology in Chresta Vell. ex DC. (Vernonieae, Asteraceae). Review of Palaeobotany and Palynology 244: 182-191.

Mandel, J.R., Barker, M.S., Bayer, R.J., Dikow, R.B., Gao, T.G., Jones, K.E., Keeley, S., Kilian, N., Ma, H., Siniscalchi, C.M., Susanna, A., Thapa, R., Watson, L. \& Funk, V.A. 2017. The Compositae tree of life in the age of phylogenomics. Journal of Systematics and Evolution 55(4): 405-410. 


\section{GENERAL REFERENCES}

Alkmim, F.F. 2012. Serra do Espinhaço e Chapada Diamantina. Pp. 236-244 In: Geologia do Brasil, Eds: Hasui, Y., Carneiro, C.D.R., Almeida, F.F.M. \& Bartorelli, A., Beca, São Paulo, Brasil.

Amarante, O.A.C., Brower, M., Zack, J. \& de Sá, A.L. (2011) Atlas do Potencial Eólico Brasileiro. Brasília.

Anderson, L.E. 1954. Hoyer's Solution as a Rapid Permanent Mounting Medium for Bryophytes. The Bryologist 57(3): 242-244.

Andrade, I.M., Mayo, S.J., Van Den Berg, C., Fay, M.F., Chester, M., Lexer, C. \& Kirpur, D. 2007. A Preliminary Study of Genetic Variation in Populations of Monstera adansonii var. klotzschiana (Araceae) from North-East Brazil, Estimated with AFLP Molecular Markers. Annals of Botany 100: 1143-1154.

Andrade, I.M., Mayo, S.J., Van Den Berg, C., Fay, M.F., Chester, M., Lexer, C. \& Kirpur, D. 2009. Genetic variation in natural populations of Anthurium sinuatum and A. pentaphyllum var. pentaphyllum (Araceae) from north-east Brazil using AFLP molecular markers. Botanical Journal of the Linnean Society 159: 88-105.

Appezzato-da-Glória, B., Cury, G., Soares, M.K.M., Rocha, R. \& Hayashi, A.H. 2008. Underground systems of Asteraceae species from the Brazilian Cerrado. The Journal of the Torrey Botanical Society 135(1): 103-113.

Avelino, A.S. 2005. Biologia reprodutiva de Lychnophora ericoides Mart. (Asteraceae: Vernonieae). Dissertação de Mestrado. Departamente de Ecologia do Instituto de Ciência Biológicas da Universidade de Brasília. Brasília, Brasil.

Bachman, S., Moat, J., Hill, A.W., Torre, J. de \& Scott, B. 2011. Supporting Red List threat assessments with GeoCAT: geospatial conservation assessment tool. ZooKeys 126: 117-126.

Badouin, H. et al. 2017. The sunflower genome provides insights into oil metabolism, flowering and Asterid evolution. Nature 546(7656): 148-152.

Baker, J.G. 1873. Compositae I. Vernoniaceae. Pp. 5-180 In Flora brasiliensis, 6(2), eds C. F. P. von Martius† and A. W. Eichler, Fried. Fleischer, Münich, Vienna, Leipzig.

Bankevich, A., Nurk, S., Antipov, D., Gurevich, A., Dvorkin, M., Kulikov, A.S., Lesin, V., Nikolenko, S., Pham, S., Prjibelski, A., Pyshkin, A., Sirotkin, A., Vyahhi, N., Tesler, G., Alekseyev, M.A., Pevzner, P.A. 2012. SPAdes: A new genome assembly algorithm and its applications to single-cell sequencing. Journal of Computational Biology 19(5): 455-477.

Barbará, T., Martinelli, G., Fay, M.F., Mayo, S.J. \& Lexer, C. 2007. Population differentiation and species cohesion in two closely related plants adapted to neotropical high-altitude 'inselbergs', Alcantarea imperialis and Alcantarea geniculate (Bromeliaceae). Molecular Ecology 16: 1981-1992.

Barbosa, A.A.A. 1997. Biologia reprodutiva de uma comunidade de campo sujo, Uberlândia/MG. Tese de doutorado. Instituto de Biologia da Universidade Estadual de Campinas. Campinas, São Paulo, Brazil.

Barreda, V.D., Palazzesi, L., Katinas, L., Crisci, J.V., Tellería, M.C., Bremer, K., Passala, M.G., Bechis, F. \& Corsolini, R. 2012. An extinct Eocene taxon of the daisy family (Asteraceae): evolutionary, ecological and biogeographical implications. Annals of Botany 109: 127-134.

Barreda, V.D., Palazzesi, L., Tallería, M.C., Olivero, E.B., Ian Raine, J. \& Forest, F. 2015. Early evolution of the angiosperm clade Asteraceae in the Cretaceous of Antarctica. PNAS 112(35): 10989-10994.

Barroso, G.M. 1947. Um gênero novo da família “Compositae”. Revista Brasileira de Biologia 7: 113-115.

Barroso, G.M. 1960. Compositae novae. Rodriguésia 35: 5-10.

Behling, H. 2002. South and southeast Brazilian grasslands during Late Quarternary times: a synthesis. Palaeogeography, Palaeoclimatology, Palaeocology 177(1-2): 19-27.

Beerling, D.J. \& Osborne, C.P. 2006. The origin of the savanna biome. Global Change Biology 12: 2023-2031.

Bentham, G. \& Hooker, J.D. 1873 (eds). Genera plantarum, Vol. 2, Part 1. Reeve \& Co., London and Williams and Norgate, London, pp. 163-533.

Blake, S.F. 1945. Dipterocypsela, a new genus of Vernonieae from Colombia. Journal of the Washington Academy of Sciences 35(2): 36-38.

Bolger, A. M., Lohse, M., \& Usadel, B. (2014). Trimmomatic: A flexible trimmer for Illumina Sequence Data. Bioinformatics 30(15): 2114-2120.

Borba, E.L., Semir, J. \& Shepherd, G.J. 2001. Self-incompatibility, inbreeding depression and crossing potential in five Brazilian Pleurothallis (Orchidaceae) species. Annals of Botany 88: 89-99. 
The Brazil Flora Group. 2015. Growing knowledge: an overview of Seed Plant diversity in Brazil. Rodriguésia 66(4): 1085-1113.

Brennan, A.C., Harris, S.A. \& Hiscock, S.J. 2003. The population genetics of sporophytic self-incompatibility in Senecio squalidus L. (Asteraceae): avoidance of mating constraints imposed by low S-allele number. Philosophical Transactions of the Royal Society of London B 358: 1047-1050.

Bringel Jr., J.B.A., Nakajima, J.N. \& Robinson, H. 2011. Allocephalus gamolepis, a new genus and species of Dipterocypselinae (Vernonieae, Asteraceae) from Central Brazil. Systematic Botany 36(3): 785-788.

Byrne, M. 2007. Phylogeography provides an evolutionary context for the conservation of a diverse and ancient flora. Australian Journal of Botany 55: 316-325

Caetano, S., Prado, D., Pennington, R.T., Beck, S., Oliveira-Filho, A., Sphichiger, R. \& Naciri, Y. 2008. The history of Seasonally Dry Tropical Forests in eastern South America: inferences from the genetic structure of the tree Astronium urundeuva (Anacardiaceae). Molecular Ecology 17: 3147-3159.

Campos, L., Guedes, M.L.S., Acevedo-Rodríguez, P. \& Roque, N. 2017. Contributions to the floristic knowledge of Espinhaço Septentrional, Bahia, Brazil. Brazilian Journal of Botany 40(2): 427-437.

Candolle, A. P. de. 1836. Vernoniaceae. Pp. 9-103 in Prodromus Systematis Naturalis Regni Vegetabilis, v. 5, Ed. A. P. de Candolle, Treutel et Würtz, Paris. Masson, Paris.

Carauta, J.P.P. 1973. The text of Velloso's Florae fluminensis and its effective date of publication. Taxon 22(2/3): 281-284.

Castelletti, C.H.M.; Santos, A.M.M.; Tabarelli, M.; Silva, J.M.C. 2003. Quanto ainda resta da Caatinga? Uma estimativa preliminar. Pp.719-734. In: Ecologia e conservação da Caatinga. (Leal, I. R.; Tabarelli, M.; Silva, J. M. C. eds.). Editora da Universidade Federal de Pernambuco, Recife.

Cavalli-Sforza, L.L. \& Edwards, A.W. 1967. Phylogenetic analysis. Models and estimation procedures. American Journal of Human Genetics 19(3 Pt 1): 233-257.

Collevatii, R.G., Rabelo, S.G. \& Vieira, R.F. 2009. Phylogeography and disjunct distribution in Lychnophora ericoides (Asteraceae), an endangered cerrado shrub species. Annals of Botany 104: 655-664.

Collevatti, R.G., Terribile, L.C., Lima-Ribeiro, M.S., Nabout, J.C., Oliveira, G., Rangel, T.F., Rabelo, S.G. \& Diniz-Filho. 2012. A coupled phylogeographical and species distribution modelling approach recovers the demographical history of a Neotropical seasonally dry forest tree species. Molecular Ecology 21: 5845-5863.

Conceição, A.S., Queiroz, L.P., Lambert, S.M., Pereira, A.C.S., Borba, E.L. 2008. Biosystematics of Chamaecrista sect. Absus subsect. Baseophyllum (Leguminosae-Caesalpinioideae) based on allozyme and morphometric analyses. Plant Systematics and Evolution 270:183-207

Coutellec-Vreto, M.A., Madec, L. \& Guiller, A. 1997. Selfing and biparental inbreeding: a mating system analysis in Lymnaea peregra (Gastropoda: Lymnaeidae). Heredity 79: 277-285.

Crawford, D.J., Lowrey, T.K., Anderson, G.J., Bernardello, G., Santos-Guerra, A. \& Stuessy, T.F. 2009. Genetic diversity in Asteraceae endemic to oceanic islands: Baker's Law and polyploid. In: Systematics, Evolution, and Biogeography of Compositae. Eds: Funk, V.A., Susanna, A., Stussey, T.F. \& Bayer, R.J. Vienna, Austria: International Association for Plant Taxonomy (IAPT). Pp. 139-151.

Cruz, D.T., Selbach-Schnadelbach, A., Lambert, S.M., Ribeiro, P.L. \& Borba, E.L. 2011. Genetic and morphological variability in Cattleya elongata Barb. Rodr. (Orchidaceae), endemic to the campo rupestre vegetation in northeastern Brazil. Plant Systematics and Evolution 294: 87-98.

Darriba, D., Taboada, G.L., Doallo, R., Posada, D. 2012. jModelTest 2: more models, new heuristics and parallel computing. Nature Methods 9(8): 772.

de Oliveira, R.S., Bezerra, L., Davidson, E.A., Pinto, F., Klink, C.A., Nepstad, D.C. \& Moreira, A. 2005. Deep root function in soil water dynamics in cerrado savannas of central Brazil. Functional Ecology 19(4): 574-581.

Donoghue, M.J., Doyle, J.A., Gauthier, J., Kluge, A.G. \& Rowe, T. 1989. The importance of fossils in phylogeny reconstruction. Annual Review of Ecology and Systematics 20: 431-460.

Dryflor. 2016. Plant diversity patterns in neotropical dry forests and their conservation implications. Science 353(6306): 1383-1387.

Earl, Dent A. and vonHoldt, Bridgett M. (2012) STRUCTURE HARVESTER: a website and program for visualizing STRUCTURE output and implementing the Evanno method. Conservation Genetics Resources 4(2): 359-361. 
Endress, P.K. 2010. Disentangling confusions in inflorescence morphology: Patterns and diversity of reproductive shoot ramification in angiosperms. Journal of Systematics and Evolution 48(4): 225-239.

Evanno et al., 2005. Detecting the number of clusters of individuals using the software STRUCTURE: a simulation study. Molecular Ecology 14: 2611-2620.

Faircloth, B.C. 2016. PHYLUCE is a software package for the analysis of conserved genomic loci. Bioinformatics 32:786-788.

Feres, F., Zucchi, M.I., Souza, A.P., Amaral, M.C.E. \& Bittrich, V. 2009. Phylogeographic studies of Brazilian "camporupestre" species: Wunderlichia mirabilis Riedel ex Baker (Asteraceae). Biotemas 22(1): 17-26.

Fiaschi, P. \& Pirani, J.R. 2009. Review of plant biogeographic studies in Brazil. Journal of Systematics and Evolution 47(5): 477-496.

Forzza, R.C., Baumgratz, J.F.A., Bicudo, C.E.M., Canhos, D.A.L., Carvalho Jr., A.A., Nadruz Coelho, M.A., Costa, A.F., Costa, D.P., Hopkins, M.G., Leitman, P.M., Lohmann, L.G., Nic Lughadha, E., Maia, L.C., Martinelli, G., Menezes, M., Morim, M.P., Peixoto, A.L., Pirani, J.R., Prado, J., Queiroz, L.P., Souza, S., Souza, V.C., Stehmann, J.R., Sylvestre, L.S., Walter, B.M.T. \& Zappi, D.C. 2012. New Brazilian floristic list highlights conservation challenges. BioScience 62(1): 39-45.

Franceschinelli, E.V., Jacobi, Drummond, M.G. \& Resende, M.F.S. 2006. The Genetic Diversity of Two Brazilian Vellozia (Velloziaceae) with Different Patterns of Spatial Distribution and Pollination Biology. Annals of Botany 97: 585-592.

Freitas, V.L.O., Lemos-Filho, J.P. \& Lovato, M.B. 2008. Contrasting genetic diversity and differentiation of populations of two successional stages in a Neotropical pioneer tree (Eremanthus erythropappus, Asteraceae). Genetics and Molecular Research 7(2): 388-398.

Funk, V.A. \& Chan, R. 2009. Introduction to Cichorioideae. In: Systematics, Evolution, and Biogeography of Compositae. Eds: Funk, V.A., Susanna, A., Stussey, T.F. \& Bayer, R.J. Vienna, Austria: International Association for Plant Taxonomy (IAPT). Pp 335-342.

Futuyma, D.J. 1987. On the role of species in anagenesis. The American Naturalist 130(3): 465-473.

Gardner, G. 1842. Characters of three new species of Chresta. London Journal of Botany 1: 238-241.

Gardner, G. 1846. Contributions towards a Flora of Brazil, being the distinctive characters of some new species of Compositae, belonging to the tribe Vernoniaceae. London Journal of Botany 5: 209-241.

Giulietti, A.M.; Bocage Neta, A.L.; Castro, A.A.J.F. et al. 2004. Diagnóstico da vegetação nativa do bioma Caatinga. In: Silva, J.M.C.; Tabarelli, M.; Fonseca, M.T.; Lins, L.V. (orgs.). Biodiversidade da Caatinga: áreas e ações prioritárias para a conservação. pp. 48-90. Ministério do Meio Ambiente, Brasília.

Glaziou, A.F.M. 1909. Plantae Brasiliae centralis a Glaziou lectae. Liste des plantes du Brésil central recueillies en 18611895. Bulletin de la Société Botanique de France 56, Mémoire 3d: 297-392.

Goloboff, P.A. \& Catalano, S.A. 2016. TNT version 1.5, including a full implementation of phylogenetic morphometrics. Cladistics 32(3): 221-238.

Gomes, V., Collevatii, R.G., Silveira, F.A.O. \& Fernandes, G.W. 2004. The distribution of genetic variability in Baccharis concinna (Asteraceae), an endemic, dioecious and threatened shrub of rupestrian fields of Brazil. Conservation Genetics 5: 157-165.

Grandcolas, P., Nattier, R., Legendre, F. \& Pellens, R. 2010. Mapping extrinsic traits such as extinction risks or modelled bioclimatic niches on phylogenies: does it make sense at all?. Cladistics 26: 1-5.

Griffin, C.A.M. \& Eckert, C.G. 2003. Experimental analysis of biparental inbreeding in a self-fertilizing plant. Evolution 57(7): 1513-1519.

Grossenbacher, D.L., Brandvain, Y., Auld, J.R., Burd, M., Cheptou, P.O., Conner, J.K., Grant, A.G., Hovick, S.M., Pannell, J.R., Pauw, A., Petanidou, T., Randle, A.M., de Casas, R.R., Vamosi, J., Winn, A., Igic, B., Busch, J.W., Kalisz, S. \& Goldberg, E.E. 2017. Self-compatibility is over-represented on islands. New Phytologist 215: 469-478.

Guindon, S. \& Gascuel, O. 2003. A simple, fast and accurate method to estimate large phylogenies by maximumlikelihood. Systematic Biology 52: 696-704.

Harris, J.G., \& Harris, M.W. 2001. Plant Identification terminology. ed. 2. Spring Lake Publishing, Spring Lake, 206 pp.

Hasui, Y. 2012. Sistema Orogênico Borborema. In: Geologia do Brasil, Eds: Hasui, Y., Carneiro, C.D.R., Almeida, F.F.M. \& Bartorelli, A., Beca, São Paulo, Brasil.

Huang, C.H., Zhang, C., Liu, M., Gao, T., Qi, J. \& Ma, H. 2016. Multiple polyploidization events across Asteraceae 
with two nested events in the early history revealed by nuclear phylogenomics. Molecular Biology and Evolution 33(11): 2820-2835.

Huang, H. \& Lacey Knowles, L. 2016. Unforeseen consequences of excluding missing data from next-generation sequences: simulation studies of RAD sequences. Systematic Biology 65(3): 357-365.

IUCN. 2012. IUCN Red List Categories and Criteria: Version 3.1. Ed 2. Gland, Switzerland and Cambridge, UK. 36 pp. Jakobsson, M. \& Rosenberg, N.A. 2007. CLUMPP: a cluster matching and permutation program for dealing with label switching and multimodality in analysis of population structure. Bioinformatics 23(14): 1801-1806.

Jesus, F.F., Solferini, V.N., Semir, J. \& Prado, P.I. 2001. Local genetic differentiation in Proteopsis argentea (Asteraceae), a perennial herb endemic in Brazil. Plant Systematics and Evolution 226: 59-68.

Jesus, F.F., Abreu, A.G., Semir, J. \& Solferini, V.N. 2009. Low genetic diversity but local genetic differentiation in endemic Minasia (Asteraceae) species from Brazil. Plant Systematics and Evolution 277: 187-196.

Jones, S.B. 1979. Synopsis and pollen morphology of Vernonia (Compositae: Vernonieae) in the New World. Rhodora 81(828): 425-447.

Keeley, S.C., Forsman, Z.H. \& Chan, R. 2007. A phylogeny of the "evil tribe" (Vernonieae: Compositae) reveals Old/ New World long distance dispersal: Support from separate and combined congruent datasets (trnL-F, ndhF, ITS). Molecular Phylogenetics and Evolution 44(2007): 89-103.

Keeley, S.C. \& Robinson, H. 2009. Vernonieae. In: Systematics, Evolution, and Biogeography of Compositae. Eds: Funk, V.A., Susanna, A., Stussey, T.F. \& Bayer, R.J. Vienna, Austria: International Association for Plant Taxonomy (IAPT). Pp. 439-469.

Koressaar, T. \& Remm, M. 2007. Enhancements and modifications of primer design program Primer3. Bioinformatics Applications Note 23(10): 1289-1291.

Lanfear, R., Calcott, B., Ho, S.Y.W., Guindon, S. 2012. PartitionFinder: combined selection of partitioning schemes and substitution models for phylogenetic analyses. Molecular Biology and Evolution 29(6): 1695-1701.

Lanfear, R., Calcott, B., Kainer, D., Mayer, C., \& Stamatakis, A. 2014. Selecting optimal partitioning schemes for phylogenomic datasets. BMC Evolutionary Biology 14(1): 82.

Las-Casas, F.M.G. 2009. Guildas de beija-flores (Aves: Trochilidae) em uma área de Caatinga, no estado de Pernambuco. M.S. thesis. Recife, PE, Brazil: Universidade Federal de Pernambuco, Departamento de Zoologia.

Lavor, P., van den Berg, C., Jacobi, C.M., Carmo, F.F. \& Versieux, L.M. 2014. Population genetics of the endemic and endangered Vrisea minarum (Bromeliaceae) in the Iron Quadrangle, Espinhaço Range, Brazil. American Journal of Botany 101(7): 1167-1175.

Leal, I.R., Vicente, A. \& Tabarello, M. 2003. Herbivoria por caprinos na Caatinga da região do Xingó: uma análise preliminar. In: Ecologia e Conservação da Caatinga. Eds: Leal, I.R., Tabarelli, M., Silva, J.M.C., Universidade Federal de Pernambuc, Recife, Brasil.

Leal, I.R., Silva, J.D., Tabarelli, M.A.R.C.; Lacher Júnior, T.E. 2005. Mudando o curso da conservação da biodiversidade na Caatinga do Nordeste do Brasil. Megadiversidade 1(1):139-146.

Lessing, C.F. 1831. De Synanthereis dissertation quarta. Linnaea 6: 624-721.

Loeuille, B., Siniscalchi, C.M., Pirani, J.R., 2014. New names in Vernonieae (Asteraceae) of northeastern Brazil. Phytoneuron 2014-9: 1-11.

Loeuille, B., Keeley, S.C. \& Pirani, J.R. 2015a. Systematics and evolution of syncephaly in American Vernonieae (Asteraceae) with emphasis on the Brazilian subtribe Lychnophorinae. Systematic Botany 40 (1): 286-298.

Loeuille, B., Semir, J., Lohmann, L.G. \& Pirani, J.R. 2015b. A phylogenetic analysis of Lychnophorinae (Asteraceae: Vernonieae) based on molecular and morphological data. Systematic Botany 40(1): 299-315.

López-Vinyallonga, S., Soriano, I., Susanna, A., Montserra, J.M., Roquet, C. \& Garcia-Jacas, N. 2015. The polyploid series of the Achillea millefolium aggregate in the Iberian Peninsual investigated using microsatellites. PLoS ONE 10(6): e0129861.

MacLeish, N.F.F. 1984a. Revision of Eremanthus Less. (Compositae: Vernonieae). University of Georgia, Athens, Georgia. PhD Thesis.

MacLeish, N.F.F. 1984b. Argyrovernonia and Paralychnophora: new names in the tribe Vernonieae (Asteraceae/ Compositae). Taxon 33: 105-106.

MacLeish, N.F.F. 1985a. Revision of Glaziovianthus (Compositae: Vernonieae). Systematic Botany 10: 347-352. 
MacLeish, N.F.F. 1985b. Revision of Chresta and Pycnocephalum (Compositae: Vernonieae). Systematic Botany 10: 459-470.

Maddison, W. P. \& Maddison, D.R. 2017. Mesquite: a modular system for evolutionary analysis. Version 3.31. http:// mesquiteproject.org

Mandel, J.R., Milton, E.F., Donovan, L.A., Knapp, S.J. \& Burke, J.M. 2013. Genetic diversity and population structure in the rare Algodones sunflower (Helianthus niveus ssp. tephrodes). Conservation Genetics 14: 31-40.

Mandel, J.R., Dikow, R.B., Funk, V.A., Masalia, R.R., Evan Staton, S., Kozik, A., Michelmore, R.W., Rieseber, L.H. \& Burke, J.M. 2014. A target enrichment method for gathering phylogenetic information from hundreds of loci: an example from the Compositae. Applications in Plant Science 2(2): 1300085.

Mandel, J.R., Dikow, R.B. \& Funk, V.A. 2015. Using phylogenomics to resolve mega-families: An example from Compositae. Journal of Systematics and Evolution 53(5): 391-402.

Mandel, J.R., Barker, M.S., Bayer, R.J., Dikow, R.B., Gao, T.G., Jones, K.E., Keeley, S., Kilian, N., Ma, H., Siniscalchi, C.M., Susanna, A., Thapa, R., Watson, L. \& Funk, V.A. 2017. The Compositae tree of life in the age of phylogenomics. Journal of Systematics and Evolution 55(4): 405-410.

Maurin, O., Jonathan Davies, T., Burrows, J.E., Daru, B.H., Yessoufou, K., Muasya, A.M., van der Bank, M. \& Bond, W.J. 2014. Savanna fire and the origins of the 'underground forests' of Africa. New Phytologist 204: 201-214.

Mayer, C. 2006-2010. Phobos 3.3.11, <http://www.rub.de/ecoevo/cm/cm_phobos.htm>.

Millar, M.A., Coates, D.J. \& Byrne, M. 2013. Genetic connectivity and diversity in inselberg populations of Acacia woodmaniorum, a rare endemic of the Yilgarn Craton banded iron formations. Heredity 111: 437-444.

Mirarab, S. \& Warnow. T. 2015. ASTRAL-II: Coalescent-Based Species Tree Estimation with Many Hundreds of Taxa and Thousands of Genes. Bioinformatics: 31(12): i44-i52. 2015.

Moritz, C. 1994. Defining 'evolutionary significant units' for conservation. TREE 9(10): 373-375.

Morjan, C.L. \& Rieserberg, L.H. 2004. How species evolve collectively: implications of gene flor and selection for the spread of advantageous alleles. Molecular Ecology 13: 1341-1356.

Moro, M.F., E. Nic Lughada, D.L. Filer, F.S. Araújo, and F.R. Martins. 2014. A catalogue of the vascular plants of the Caatinga Phytogeographical Domain: a synthesis of floristic and phytosociological surveys. Phytotaxa 160(1): 1-118.

Nakajima, J.N. 2000. A família Asteraceae no Parque Nacional da Serra da Canastra, Minas Gerais, Brasil. Tese de Doutorado. Instituto de Biologia da Universidade Estadual de Campinas. Campinas, São Paulo, Brasil.

Neves, D.M., Dexter, K.G., Toby Pennington, R., Bueno, M.L. \& Oliveira Filho, A.T. 2015. Environmental and historical controls of floristic composition across the South American Dry Diagonal. Journal of Biogeography 42(8): 1566-1576.

Nordenstam, B. \& Funk, V.A. 2009. Corymbieae. In: Systematics, Evolution, and Biogeography of Compositae. Eds: Funk, V.A., Susanna, A., Stussey, T.F. \& Bayer, R.J. Vienna, Austria: International Association for Plant Taxonomy (IAPT). Pp 487-491.

Panero, J.L. \& Crozier, B.S. 2016. Macroevolutionar dynamics in the early diversification of Asteraceae. Molecular Phylogenetics and Evolution 99: 116-132.

Peakall, R. \& Smouse, P.E. 2006. GENALEX 6: genetic analysis in Excel. Population genetic software for teaching and research. Molecular Ecology Notes 6: 288-295.

Peakall, R. \& Smouse, P.E. 2012. GENALEX 6.5: genetic analysis in Excel. Population genetic software for teaching and research - an update. Bioinformatics 28: 2537-2539.

Pennington, R.T., Richardson, J.E. \& Lavin, M. 2004. Insights into the historical construction of species-rich biomes from dated plant phylogenies, neutral ecological theory and phylogenetic community structure. New Phytologist 172(4): 605-616.

Pennington, R.T. \& Hughes, C.E. 2014. The remarkable congruence of New and Old World savanna origins. New Phytologist 204: 4-6.

Pereira, A.C.S., Borba, E.L., Giulietti, A.M. 2007. Genetic and morphological variability of the endangered Syngonanthus mucugensis Giul. (Eriocaulaceae) from the Chapada Diamantina, Brazil: implications for conservation and taxonomy. Botanical Journal of the Linnean Society 153(4): 401-416.

Philipson, W.R. 1938. Four new species of Vernonieae collected by Glaziou in Brasil. Bulletin of Miscellaneous Information (Royal Botanic Gardens, Kew) 7: 298-300. 
Pinheiro, F., Cozzolino, S., Draper, D., Barros, F., Félix, L.P., Fay, M.F. \& Palma-Silva, C. 2014. Rock outcrop orchids reveal the genetic connectivity and diversity of inselbergs of northeastern Brazil. BMC Evolutionary Biology 14: 49.

Porembski S., Barthlott W. 2000. Inselbergs. Biotic Diversity of Isolated Rock Outcrops in Tropical and Temperate Regions. Springer- Verlag, Berlin, Heidelberg, New York.

Prado, D.E. 2000. Seasonally dry forests of tropical South America: from forgotten ecosystems to a new phytogeographic unit. Edinburgh Journal of Botany 57(3): 437-461.

Prado, D.E. \& Gibbs, P.E. 1993. Patterns of species distribution in the Dry Seasonal Forests of South America. Annals of the Missouri Botanical Garden 80(4): 902-927.

Pritchard, J.K., Stephens, M. \& Donnelly, P. 2000. Inference of population structure using multilocus genotype data. Genetics 155: 945-959.

Raymond, M., Rousset, F. 1995. GENEPOP (version 1.2): population genetics software for exact tests and ecumenicism. Journal of Heredity 86: 248-249.

Ribeiro, E.M.S., Arroyo-Rodríguez, V., Santos, B.A., Tabarelli, M. \& Leal, I.R. 2015. Chronic anthropogenic disturbance drives the biological impoverishment of the Brazilian Caatinga vegetation. Journal of Applied Ecology 52: 611-620.

Rizzini, C.T. \& Heringer, P. 1961. Underground organs of plants from some southern Brazilian savannas, with special reference to the xylopodium. Phyton 17: 105-124.

Robinson, H. 1979. Two new genera of Vernonieae (Asteraceae) from Brazil Heterocypsela and Pseudostifftia. Phytologia 44: 442-450.

Robinson, H. 1980. Notes on the Lychnophorinae genera Chresta and Eremanthus (Vernonieae: Asteraceae). Phytologia 45: 89-100.

Robinson, H. 1983. A new species of Chresta from Bahia, Brasil (Vernonieae: Asteraceae). Phytologia 53(6): $385-387$.

Robinson, H. 1992. Notes on the Lychnophorinae from Minas Gerais, Brazil, a synopsis of Lychnophoriopsis SchultzBip., and the new genera Anteremanthus and Minasia (Vernonieae: Asteraceae). Proceedings of the Biological Society of Washington 105: 640-652.

Robinson, H. 1999a. Generic and subtribal classification of American Vernonieae. Smithsonian Contributions to Botany 89. 116 pp.

Robinson, H. 1999b. Revisions in paleotropical Vernonieae (Asteraceae). Proceedings of the Biological Society of Washington 112(1): 220-247.

Robinson, H. 2005. New species and new combinations in the tribe Vernonieae (Asteraceae). Phytologia 87(2): 80-96.

Roque, N.; Gonçalves, J.M. \& Dematteis, M. 2008. A new species of the Brazilian genus Chresta (Asteraceae, Vernonieae) from Bahia. Botanical Journal of the Linnean Society 157: 587-590.

Rosenberg, N.A. 2004. DISTRUCT: a program for the graphical display of population structure. Molecular Ecology Notes 4: 137-138.

Ross, J.L.S. 1998. Geografia do Brasil. Ed. 2. EDUSP. São Paulo.

Roubik, D.W. 1989. Ecology and Natural History of Tropical Bees. Cambridge Tropical Biology Series. Cambridge University Press, USA.

Rousset, F. 2008. Genepop'007: a complete reimplementation of the Genepop software for Windows and Linux. Molecular Ecology Resources 8: 103-106.

Sarthou, C., Samadi, D. \& Boisselier-Dubayle, M.C. 2000. Genetic structure of the saxicole Pitcairnia geyskesii (Bromeliaceae) on inselbergs in French Guiana. American Journal of Botany 88(5): 861-868.

Scheiter, S., Higgins, S.I., Osborne, C.P., Bradshaw, C., Lunt, D., Ripley, B.S., Taylor, L.L., Beerling, D.J. 2012. Fire and fire-adapted vegetation promoted C4 expansion in the late Miocene. New Phytologist 195(3): 653-666.

Schuelke, M. 2000. An economic method for the fluorescent labeling of PCR fragments. Nature Biotechnology 18: 233-234.

Schultz-Bipontinus, C.H. 1861. Cassiniaceae uniflorae, oder Verzeichniss der Cassiniaceen mit 1-blüthigen Köpfchen. Jahresbericht der Pollichia 18/19: 157-190.

Schultz-Bipontinus, C.H. 1863. Lychnophora Martius! und einige benachbarte Gattungen. Jahresbericht der Pollichia 20/21: 321-439.

Shaw, J., Lickey, E.B., Beck, J.T., Farmer, S.B., Liu, W., Miller, J., Siripun, K.C., Winder, C.T., Schilling, E.E. \& Small, R.L. 2005. The tortoise and the hare II: relative utility of 21 noncoding chloroplast DNA sequences for phylogenetic 
analysis. American Journal of Botany 92(1): 142-166.

Shepherd, L.D. \& McLay, T.G.B. 2011. Two micro-scale protocols for the isolation of DNA from polysaccharide-rich plant tissue. Journal of Plant Research 124: 311-314.

Silva, A.A.R., Bezerra, M.M., Chaves, H.V., Pereira, K.M.A., Aguiar, J.A., Pinto, V.P.T., Abbet, C., Simões-Pires, C.A., Franco, E.S., Henriques, A.T., Hostettmann, K. \& Maia, M.B.S. 2013. Protective effect of Chresta martii extract against indomethacin-induced gastric lesions in mice. Journal of Natural Medicines 67: 143-151.

Simon, M.F., Grether, R., Queiroz, L.P., Skema, C., Pennington, R.T. \& Hughes, C.E. 2009. Recent assembly of the Cerrado, a neotropical plant diversity hotspot, by in situ evolution of adaptations to fire. PNAS 106(48): 2035920364.

Simon, M.F. \& Pennington, T. 2012. Evidence for Adaptation to Fire Regimes in the Tropical Savannas of the Brazilian Cerrado. International Journal of Plant Sciences 173(6): 711-723.

Siniscalchi, C.M., Loeuille, B.F.P., Pirani, J.R., 2016. A new species of Chresta (Vernonieae, Asteraceae) endemic to the Mata Atlântica Domain, Brazil. Phytotaxa 244(1): 80-88.

Siniscalchi, C.M., Souza-Souza, R.M.B., Loeuille, B., Pirani, J.R. \& Gonçalves-Esteves, V. 2017. The systematic value of pollen morphology in Chresta Vell. ex DC. (Vernonieae, Asteraceae). Review of Palaeobotany and Palynology 244: 182-191.

Sisó, S., Camarero, J.J., Gil-Pelegrín, E. 2001. Relationship between hydraulic resistance and leaf morphology in broadleaf Quercus species: a new interpretation of leaf lobation. Trees 15: 341-345.

Small, J. 1919. The origin and development of the Compositae. New Phytologist Reprint 11, 354 pp.

Souza, M.J.N., \& V.P.V. Oliveira. 2006. Os enclaves úmidos e sub-úmidos do semi-árido do nordeste brasileiro. Mercator 5(9): 85-102.

Stamatakis A. 2006. RAxML-VI-HPC: maximum likelihood-based phylogenetic analyses with thousands of taxa and mixed models. Bioinformatics 22: 2688-2690.

Stamatakis, A. 2014. RAxML Version 8: A tool for Phylogenetic Analysis and Post-Analysis of Large Phylogenies. Bioinformatics 30(9): 1312-1313.

Tabarelli, M. \& Santos, A.M.M. 2004. Uma breve descrição sobre a história natural dos brejos nordestinos. In: Brejos de Altitude em Pernambuco e Paraíba, História Natural, Ecologia e Conservação. Eds: Pôrto, K.C., Cabral, J.J.P., Taberelli, M., Ministério do Meio Ambiente, Universidade Federal de Pernanbuco, Brasília, DF. Pp 17-24.

Takezaki, N., Nei, M. \& Tamura, K. 2010. POPTREE2: Software for constructing population trees from allele frequency data and computing other population statistics with Windows-interface. Molecular Biology and Evolution 27: 747-752.

Taubert, P. 1896. Beiträge zur Kenntnis der Flora des centralbrasilianischen Staates Goyaz. Botanisch Jahrbücher fur Systematik, Pflanzengeschichte und Pflanzengeographie 21: 402-457.

Thiers, B. [continuously updated]. Index Herbariorum: A global directory of public herbaria and associated staff. New York Botanical Garden's Virtual Herbarium. http://sweetgum.nybg.org/science/ih/.

Timmee, R.E., Kuehl, J.V., Boore, J.L. \& Jansen, R.K. 2007. A comparative analysis of the Lactuca and Helianthus (Asteraceae) plastid genomes: identification of divergent regions and categorization of shared repeats. American Journal of Botany 94(3): 302-312.

Turchetto-Zolet, A.C., Pinheiro, F., Salgueir, F. \& Palma-Silva, C. 2013. Phylogeographical patterns shed light on evolutionary process in South America. Molecular Ecology 22(5): 1193-1213.

Untergasser A, Cutcutache I, Koressaar T, Ye J, Faircloth BC, Remm M, Rozen SG. 2012. Primer3 - new capabilities and interfaces. Nucleic Acids Research 40(15): e115.

Velloso, J.M.C. 1831 (1827). Flora Fluminensis Icones, vol 3. Parisiis [Paris]: ex off. lithogr. Senefelder.

Vieira, F.A., Novaes, R.M.L., Fajardo, C.G., Santos, R.M., Almeida, H.S., Carvalho, D. \& Lovato, M.B. 2015.

Holocene southward expansion in seasonally dry tropical forests in South America: phylogeography of Ficus bonijesulapensis (Moraceae). Botanical Journal of the Linnean Society 177: 189-201.

Vogel, S. 1968. "Sun leaves" and "shade leaves": differences in convective heat dissipation. Ecology 49(6): 1203-1204. Vogel, S. 2015. Vertebrate pollination in Compositae: Floral Syndromes and Field Observations. Stapfia 103 : 5-26.

Weitemeier, K., Straub, S.C.K., Cronn, R.C., Fishbein, M., Schmickl, R., McDonnell, A. \& Liston, A. 2014. Hyb-Seq: Combining target enrichment and genome skimming for plant phylogenomics. Applications in Plant Sciences 2(9): 1400042. 
Wiens, J.J. 2003. Missing data, incomplete taxa, and phylogenetic accuracy. Systematic Biology 52(4): 528-538.

Wiens, J.J. \& Morrill, M.C. 2011. Missing data in phylogenetic analysis: reconciling results from simulations and empirical data. Systematic Biology 60(5): 719-731.

Wurdack, J.J. 1970. Erroneous data in Glaziou collections of Melastomataceae. Taxon 19(6): 911-913.

Yu, Y., Harris, A.J. \& He, X. 2010. S-DIVA (Statistical Dispersal-Vicariance Analysis): A tool for inferring biogeographic histories. Molecular Phylogenetics and Evolution 56(2): 848-850.

Yu, Y., Harris, A.J., Blair, C. \& He, X. 2015. RASP (Reconstruct Ancestral State in Phylogenies): A tool for historical biogeography. Molecular Phylogenetics and Evolution

Zardini, E.M. 1976. Una segunda especie del gênero Glaziovianthus Barroso (Compositae - Vernonieae). Boletin de la Sociedad Argentina de Botánica 17(3-4): 239-240. 